\title{
Larval behavior regulates nearshore retention and offshore migration in an upwelling shadow and along the open coast
}

\author{
Steven G. Morgan ${ }^{1,2, *}$, Jennifer L. Fisher ${ }^{1}$ \\ ${ }^{1}$ Bodega Marine Laboratory, University of California Davis, 2099 Westside Drive, Bodega Bay, California 94923-0247, USA \\ ${ }^{2}$ Department of Environmental Science and Policy, University of California Davis, 1 Shields Avenue, Davis, \\ California 93510, USA
}

\begin{abstract}
Larvae are considered to be highly susceptible to offshore transport, thereby limiting recruitment in productive upwelling regions, except in the recirculation features that form in the lee of headlands. We show that 19 of 20 taxa of nearshore crustaceans were at least as common on the open coast as they were in the lee of a headland in a recruitment-limited region characterized by strong upwelling. Nine of these taxa occurred in high concentrations throughout development, indicating that larvae completed development nearshore in a coastal boundary layer of reduced Ekman transport. Larvae of 9 more taxa were prevalent as early stage larvae, and later stages were uncommon, indicating that larvae migrated offshore. The relative abundance of larval stages largely matched the vertical distributions of larvae in this study and a previous cross-shelf survey at this site, indicating that larval behavior plays a substantial role in determining whether larvae complete development nearshore or migrate offshore later in development. Larvae of taxa that occurred nearshore in high concentrations throughout development resided below a shallow Ekman layer of seaward-flowing surface waters, whereas most larvae of the other taxa occurred closer to the surface. Whether larvae undertook ontogenetic and diel vertical migrations also appeared to determine whether they were retained nearshore. Thus larval retention may be more widespread in upwelling regions than is widely believed, and the cause of recruitment limitation along upwelling coasts needs to be determined to further advance our understanding of the connectivity, dynamics and structure of coastal populations.
\end{abstract}

KEY WORDS: Larval behavior $\cdot$ Larval transport $\cdot$ Recruitment limitation $\cdot$ Upwelling $\cdot$ Population dynamics $\cdot$ Community structure

\section{INTRODUCTION}

Larval transport is a key determinant affecting the dynamics and structure of populations and communities (Morgan 1995, 2001, Underwood \& Keough 2001). Transport often is determined by the vertical distributions of larvae in vertically stratified currents, where larvae near the surface frequently are carried in the opposite direction to larvae at depth (Queiroga \& Blanton 2004, Morgan 2006). This enables larvae to remain nearby or migrate various distances from natal popula- tions (Morgan 1995, 2006, Sponaugle et al. 2002, Swearer et al. 2002).

Larval transport is especially important in regulating populations in recruitment-limited regions along western margins of continents (Yoshioka 1982, Roughgarden et al. 1988, Wing et al. 1995). It more strongly influences the distribution and abundance of adults than in density-dependent regions where settlement and post-settlement mortality are high (Broitman et al. 2001, Connolly et al. 2001, Menge et al. 2004, Rilov \& Schiel 2006). Strong winds coupled with the Coriolis 
effect drive surface waters offshore (Ekman transport), potentially limiting the number of recruits to coastal communities and subsequent interactions among them in regions of persistent upwelling. Peak recruitment onshore was proposed to occur infrequently and episodically when winds weaken (relax) or reverse, delivering larvae either onshore (Farrell et al. 1991, Roughgarden et al. 1992) or alongshore from retention hotspots in the lee of capes (Wing et al. 1995, 1998, Graham \& Largier 1997).

Retention hotspots may be more common than previously thought by occurring even in the lee of small headlands (Roughan et al. 2005, Mace \& Morgan 2006a). Invertebrate larvae were found to recruit more in the lee of the small promontory of Bodega Head, California, than on the adjacent open coast (Mace \& Morgan 2006a). The low-lying headland partially blocks the prevailing upwelling wind so that surface waters flow equatorward, as they do along the open coast, but recirculation occurs at depth (Roughan et al. 2005). Larvae originating in the lee of the headland or recruiting from elsewhere could remain there either by staying deep in the water column or by undertaking diel vertical migrations between surface and bottom currents (Roughan et al. 2005). The entrainment and retention of larvae in the lee of both large and small headlands is thought to occur only while upwelling-favorable winds prevail, because recirculation features may dissipate when winds relax or reverse (Wing et al. 1995, Graham \& Largier 1997). During relaxation events, larvae are transported around headlands in a poleward-flowing coastal boundary current supplying larvae to recruitment-limited populations along the open coast (Wing et al. 1995, 2003, Lundquist et al. 2000).

It is also possible that larvae may remain close to shore in a retentive coastal boundary layer of weaker cross-shelf and alongshore flow that forms within $10 \mathrm{~km}$ of the shore (Lentz \& Chapman 1989, Largier et al. 1993, Kaplan \& Largier 2006, Roughan et al. 2006). Larvae of some species may remain close to shore throughout their lives by remaining below a shallow Ekman layer or only rising into productive surface waters to forage at night when offshore flow is weakest (Peterson 1998, Batchelder et al. 2002, dos Santos et al. 2008, Morgan et al. 2009a,c, Shanks \& Shearman 2009). In contrast, larvae of species that ascend to surface waters after hatching may be transported offshore by Ekman transport and return to shore by descending into onshore flow generated by upwelling (Peterson 1998, Papastephanou et al. 2006, Morgan et al. 2009c) or by rising into the neuston where internal waves or infrequent wind relaxations transport them shoreward (Hobbs et al. 1992, Shanks 1995, Pineda 1999, Poulin et al. 2002). Determining the extent to which larvae remain nearshore in the lee of small headlands and on exposed coasts is vital to understanding the connectivity, dynamics and structure of populations in upwelling regions throughout the world.

The purpose of the present study was to determine (1) whether larvae are retained more effectively in the lee of small headlands than on the open coast, (2) the proportion of species that remain nearshore or migrate offshore and, (3) the larval behaviors responsible for nearshore retention and offshore migration. To address these questions, we profiled vertical distributions of larvae relative to water column structure in the lee of Bodega Head and on the adjacent exposed coast and determined the abundance and stage of development for 20 taxa of crustacean larvae. All larval stages should be abundant if larvae are retained nearshore, whereas only the first and last larval stages should be present if larvae migrate offshore. Larvae of species that complete development nearshore should remain deep in the water column throughout the day. Seaward transport also might be slowed if larvae rise to the surface only at night when winds subside and surface currents slow or reverse. Early larval stages of species that migrate offshore should occur higher in the water column where they would be prone to Ekman transport. The present study was conducted in the strongest upwelling region along the west coast of the USA (Dorman et al. 2006) during the peak upwelling season when offshore transport should be greatest and most nearshore species develop in the plankton (Shanks \& Eckert 2005, Mace \& Morgan 2006a).

\section{MATERIALS AND METHODS}

Study system. The present study was conducted in and directly outside Bodega Bay along the open coast in northern California, USA (Fig. 1). Strong, upwellingfavorable winds persist for weeks during the peak upwelling season, which occurs during spring and summer in the Northern Hemisphere (Hickey 1998). Near-surface waters $(<50 \mathrm{~m})$ across the entire shelf flow equatorward and offshore (Largier et al. 1993, Roughan et al. 2006). The coastline topography and shallow depths reduce offshore Ekman transport and slow alongshore currents in a coastal boundary layer that occurs $<10 \mathrm{~km}$ from shore (Lentz \& Chapman 1989, Largier et al. 1993, Kaplan \& Largier 2006, Roughan et al. 2006). Prevailing northwesterly winds weaken or reverse for several days about every 4 to $10 \mathrm{~d}$ (Hickey 1998), and flow moves northward and onshore in less than a day over the inner shelf (Send et al. 1987, Largier et al. 1993, Roughan et al. 2006).

Bodega Bay faces southwest on the leeward side of a small headland. The bay mouth is approximately $11 \mathrm{~km}$ wide from the northern tip at Bodega Head to the 
southern tip at Tomales Point and is 20 to $25 \mathrm{~m}$ deep. Upwelling is active in the windexposed bay, where newly upwelled surface waters move offshore and equatorward (Roughan et al. 2005). Recirculation occurs at depth in the lee of the headland during upwelling conditions (Roughan et al. 2005). Tides are mixed semidiurnal with a tidal range of 1.2 to $2.9 \mathrm{~m}$. The headland primarily consists of rocky habitat but the bay consists of sandy beaches, boulder fields and soft bottoms.

Barnacles in this region (Balanus crenatus, B. glandula, B. nubilus and Chthamalus spp.) molt through 6 larval stages and a postlarval stage (cyprid), spending about 2 to 4 wk in the plankton (Strathmann 1987). The anomuran and brachyuran crabs in the study region spend weeks to months in the plankton, developing through 2 to 5 larval stages and a postlarval stage (megalopa) before returning to the benthos as juveniles (reviewed by Lough 1974, Morris et al. 1980, Shanks \& Eckert 2005). Cancrids recruit to Bodega Bay yearround, peaking in May and June, while the remaining taxa peak from May to August (Morris et al. 1980, Mace \& Morgan 2006a).

Sampling. The spatial and vertical distributions of larvae were determined from 8 cruises that were conducted from 15 June

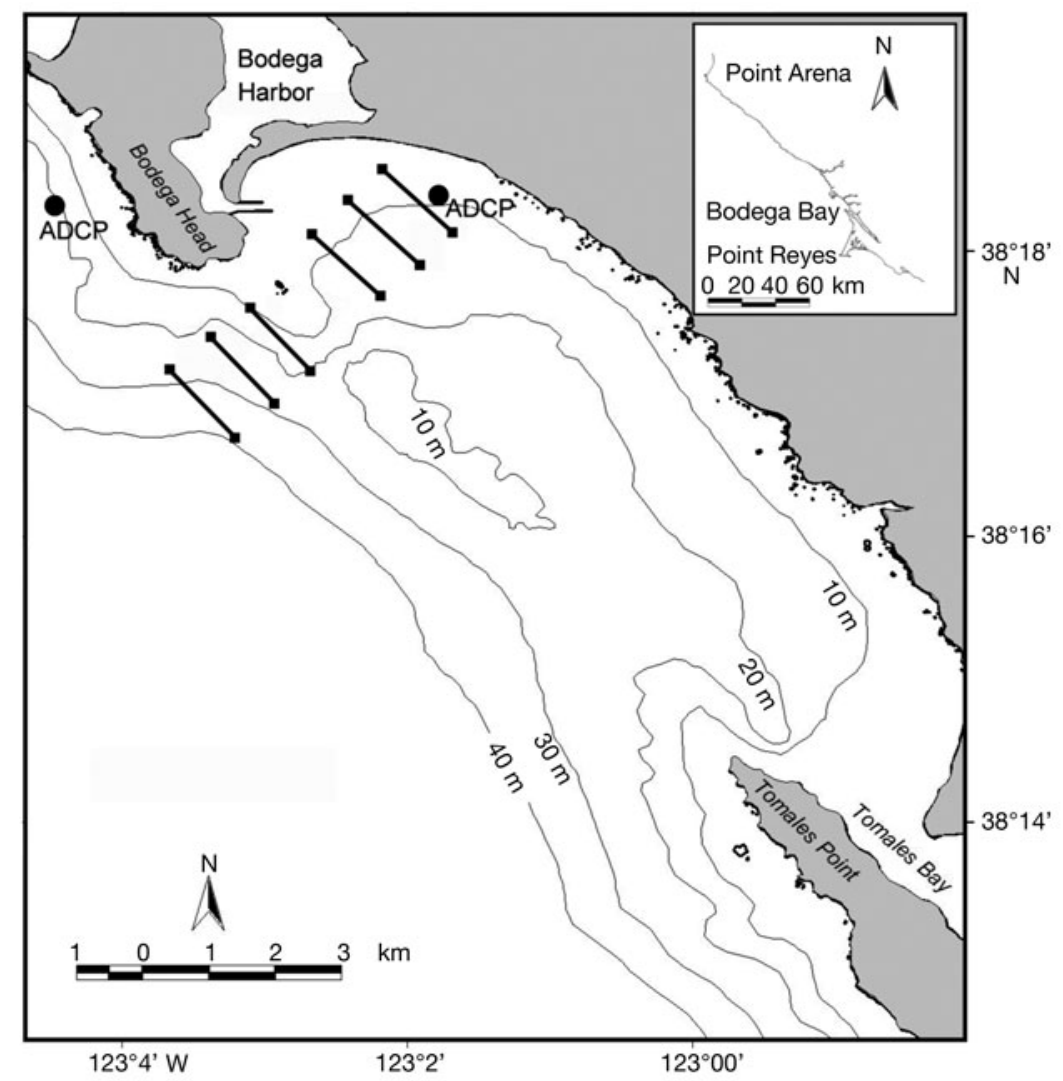

Fig. 1. Replicate transects sampled within $1 \mathrm{~km}$ from shore and inside Bodega Bay, California, USA. Solid circles depict the locations of the acoustic Doppler current profilers (ADCP) located in the lee of Bodega Head and along the open coast

to 5 August 2005. Larvae were sampled in the lee of Bodega Head in $15 \mathrm{~m}$ of water (Fig. 1). They were also sampled within $1 \mathrm{~km}$ offshore of the headland along the open coast in $\sim 20 \mathrm{~m}$ of water during each cruise. Three replicate transects extended parallel to the axis of the bay mouth both inside and outside the bay during each cruise. Sampling was conducted during the daytime during all cruises and at night during 1 cruise (5 August) to determine whether diel vertical migrations were evident.

Larvae were collected using an electronically tripped Tucker Trawl $\left(0.5 \mathrm{~m}^{2}\right.$ mouth) that was equipped with three $335 \mu \mathrm{m}$ mesh nets and temperature and depth sensors to interactively sample relative to the thermocline. The shallow water column was partitioned into 2 depth bins and sampled equally. A neuston net $\left(0.5 \mathrm{~m}^{2}\right.$ mouth) sampled the surface of the water column. A flow meter (General Oceanics, model 2030) was fit to the mouth of each net to determine the volume of water sampled.

Physical conditions were monitored from 7 June to 10 August 2005 to bracket larval surveys. Continuous wind and sea surface temperature data were obtained from a meteorological buoy located $28 \mathrm{~km}$ offshore of Bodega Bay (National Data Buoy Center buoy 46013, $38^{\circ} 13^{\prime} 30^{\prime} \mathrm{N}, 123^{\circ} 19^{\prime} 00^{\prime} \mathrm{W}$; www.ndbc.noaa.gov) to place cruises in the context of larger oceanographic forcing. Upwelling was considered to occur when $36 \mathrm{~h}$ low-pass filtered equatorward winds were $\geq 5 \mathrm{~m} \mathrm{~s}^{-1}$ and water temperatures were decreasing or $<10^{\circ} \mathrm{C}$. Relaxation occurred when equatorward wind speeds were $<3 \mathrm{~m} \mathrm{~s}^{-1}$, and downwelling occurred when winds were poleward.

Water column properties were profiled at the beginning and end of each transect to place larval distributions in the context of water column structure and circulation patterns. Temperature and salinity profiles were taken using a profiling CTD (Seabird Electronics, SBE-19 Plus). Current velocity was measured continuously using bottom-mounted acoustic Doppler current profilers (ADCP) located in northern Bodega Bay (RDI, $1200 \mathrm{kHz}$ ) at a water depth of $10 \mathrm{~m}$ and along the open coast (RDI, $300 \mathrm{kHz}$ ) in $30 \mathrm{~m}$ of water (Fig. 1). Velocity data were collected in 1 and $2 \mathrm{~m}$ depth bins and 3 and 10 min ensembles, respectively. Velocity ensembles were averaged hourly at both sites and rotated in the 
alongshore direction to a depth-averaged principal axis of $332.5^{\circ}$ True inside the bay and $300.4^{\circ}$ True along the open coast. Representative temperature and salinity profiles during upwelling and relaxation conditions in the lee of the headland and on the open coast are presented together with continuous alongshore current velocities at the surface and bottom of the water column at each location.

Data analysis. All crustacean larvae were identified to species and stage, and counts were standardized to number per volume of water sampled. Samples were split using a Folsom plankton splitter depending on larval concentrations. The barnacles Chthamalus dalli and $C$. fissus could not be reliably distinguished. However, they most likely consisted of $C$. dalli given that the northern range limit of $C$. fissus occurs to the south of our study area at San Francisco Bay (Wares \& Castañeda 2005). The shore crabs Hemigrapsus oregonensis and $H$. nudus both occur in the study area but were not distinguished. The identity of 1 pagurid is unknown.

The total number of larvae collected, the mean larval density per sampling trip and percent larval densities were calculated for each species. Some closely related taxa (porcellanids, Mimulus foliatus/Pugettia richii, Scyra acutifrons/P. producta and Cancer oregonensis/ C. productus) were combined for presentation after determining that the relative abundance and vertical and spatial distribution of larval stages were similar.

We explored the relationship between the larval community across upwelling and relaxation cycles and at the 2 sites and 3 depths using non-metric multidimensional scaling (NMDS) and non-parametric analysis of similarities (ANOSIM). The ANOSIM test statistic (R) is a useful measure of community separation between factors, with zero indicating no separation and 1 indicating complete separation (Clark \& Warwick 2001). Analyses were conducted using PRIMER software (version 6.1.10). Data were square-root transformed to deemphasize the contribution of very abundant species, and all analyses were conducted on a Bray-Curtis similarity matrix. A 1-way ANOSIM using data that were averaged across site and depth tested for differences in the larval community over time and during upwelling and relaxation conditions. A 2-way crossed ANOSIM using date-averaged data tested for overall horizontal (site) and vertical (depth) structure in the larval community.

The relative densities of larval stages in the bay and along the open coast were reported to indicate whether larvae of each taxon were retained nearshore throughout development or migrated onto the shelf before recruiting onshore as postlarvae. The vertical distributions of larval stages were reported to indicate whether depth regulation enabled some species to complete development nearshore while others did not. Larval stages were combined into early, mid, late and postlarvae to simplify presentation. Porcellanids and majids were combined into early and late stages, because they have only 2 larval stages and a postlarval stage.

ANOVA was used to examine interspecific differences in vertical distributions by developmental stage and time of day. A blocked 2-way ANOVA was conducted for each taxon to determine whether the distribution of larval stages differed between the 2 sites. This indicated whether most larvae were released inside the bay or on the open coast and occurred at either location throughout development. Sampling location was not included in analyses involving depth, because the 2-way crossed ANOSIM detected little difference in depth distributions of the larval community between the 2 sampling locations. Therefore, a blocked 2-way ANOVA determined whether ontogenetic shifts in vertical distributions occurred (depth $\times$ stage interaction), using data that were averaged by site. Both analyses were blocked by sampling date to account for differences in larval abundance and stage distributions through time as indicated by NMDS. A 2-way ANOVA also revealed whether diel vertical migrations were evident (depth $\times$ day/night interaction) using data from the 1 cruise in which samples also were collected at night. We first conducted a 3-way ANOVA to determine that 3 -way interactions (depth $\times$ diel $\times$ stage) did not occur before reporting results of the simpler 2-way ANOVA for each of the 20 taxa. For all tests, larval densities were transformed $\left(\log _{10} x+1\right)$ to meet assumptions of homogeneity of variances and normality. Student's $t$-test (multiple comparisons) detected differences in larval densities between sites and over the diel cycle. Tukey's HSD (multiple comparisons) revealed differences in densities among depths.

\section{RESULTS}

\section{Water column structure}

Four cruises were conducted during upwelling conditions and 4 were conducted during relaxation. Two cruises followed weeks of strong equatorward winds when the water column was fairly well mixed, cold and saline in the bay and along the open coast (Fig. 2A). Two more cruises occurred following days of upwelling when the water column was well mixed, slightly warmer and fresher in the bay than on the open coast. The water column was stratified both in the bay and along the open coast during all cruises that were conducted during relaxation conditions (Fig. 2B). 
A

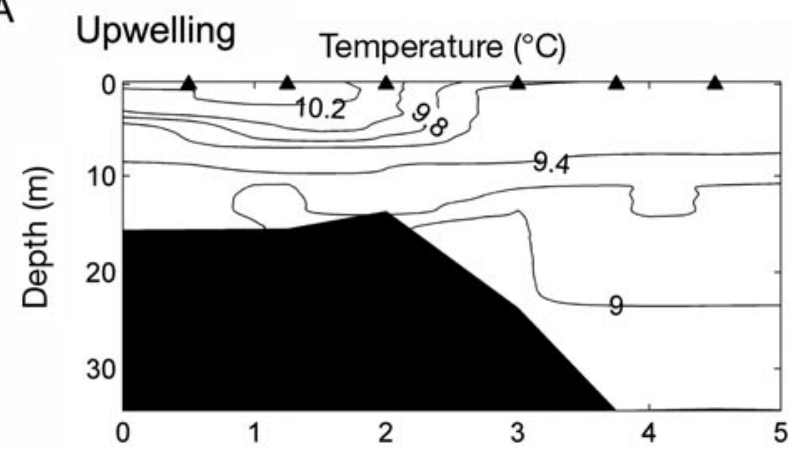

B

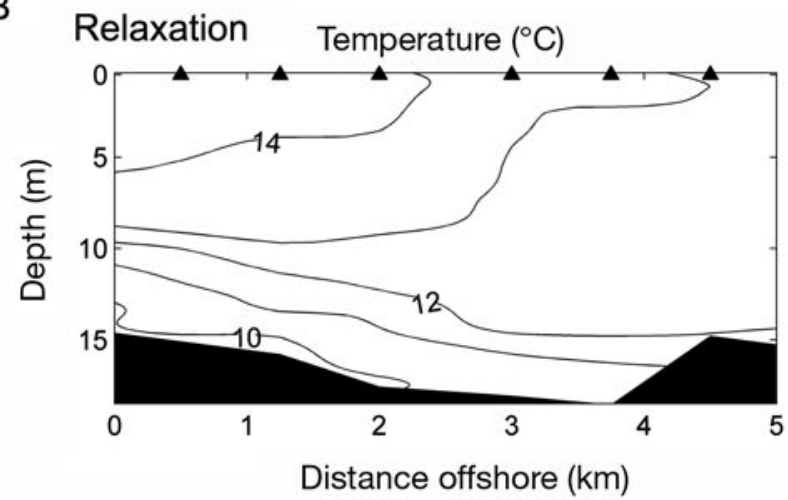

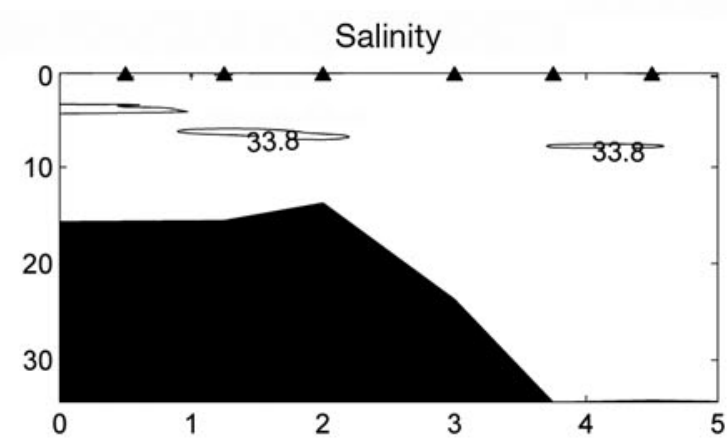

Salinity

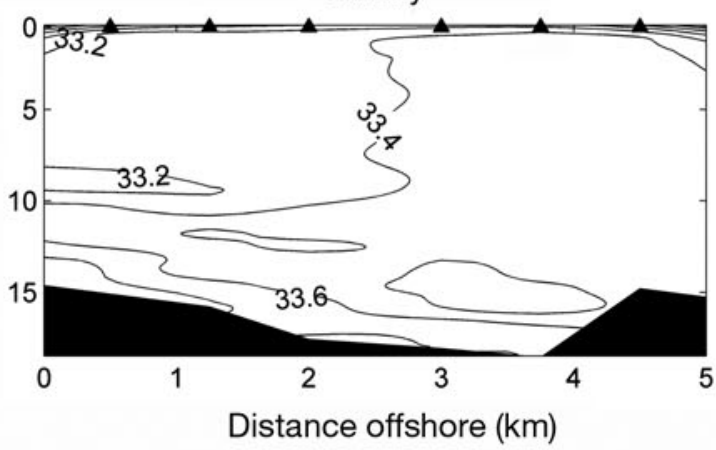

C

Alongshore inside

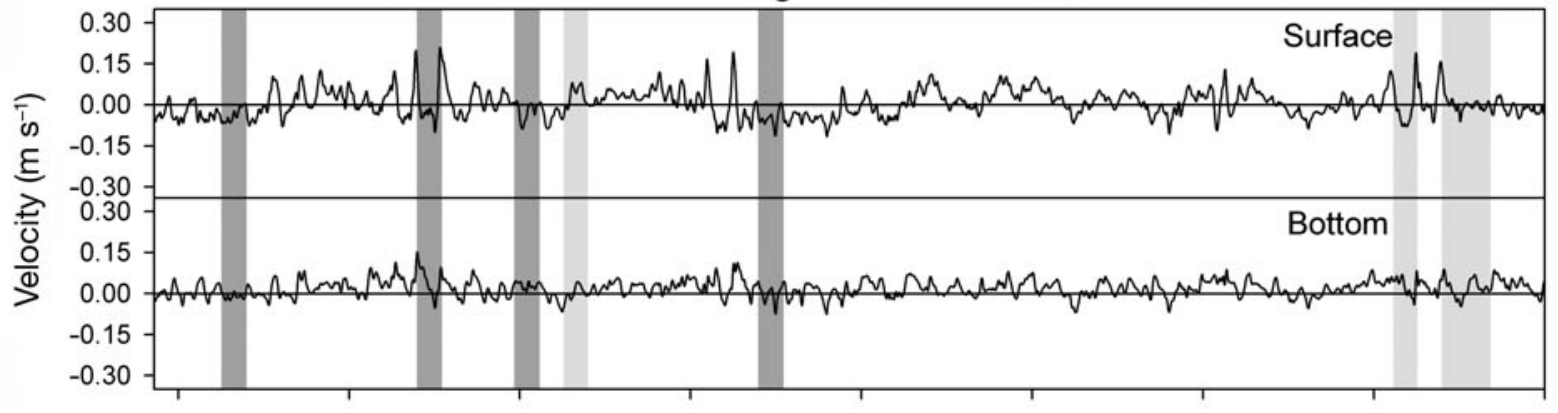

D

Alongshore outside

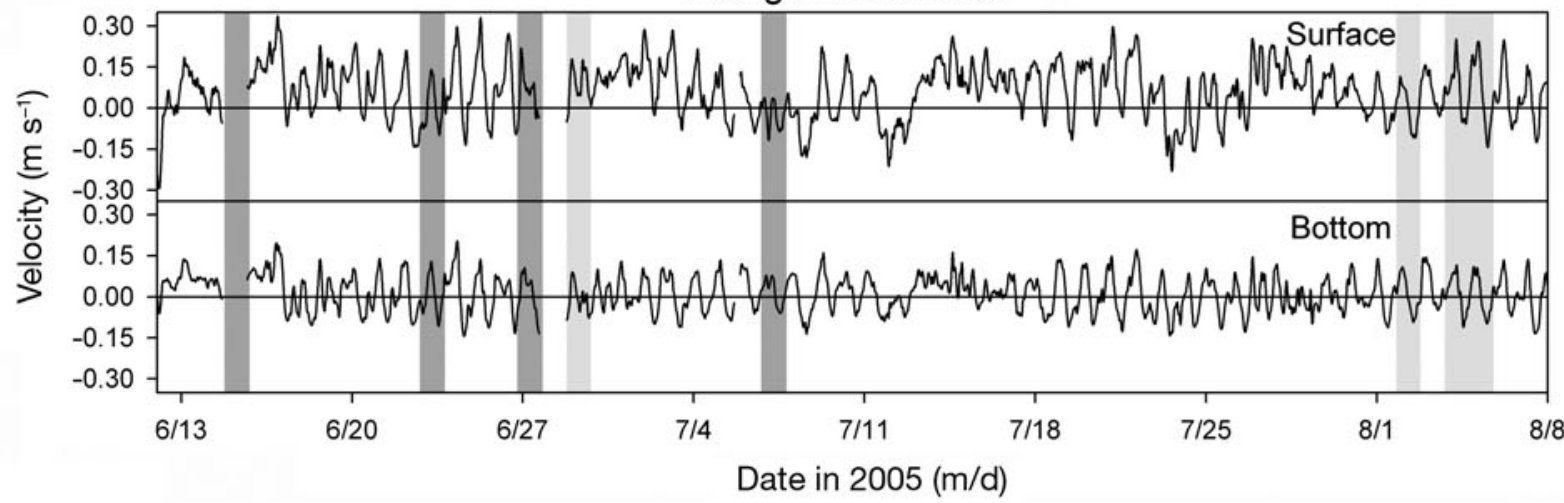

Fig. 2. (A,B) Contours of temperature (left) and salinity (right) at the beginning of 6 transects during (A) upwelling on 7 July 2005 and (B) relaxation conditions on 2 August 2005. Sample locations are indicated by solid triangles. (C,D) Continuous alongshore water velocities at the surface and bottom $(\mathrm{C})$ inside Bodega Bay (inside) and (D) within $1 \mathrm{~km}$ from shore (outside) of the headland. Positive alongshore flow is poleward, negative alongshore flow is equatorward. Dark gray vertical bars indicate cruises conducted during upwelling, and light gray bars reflect cruises conducted during relaxation. Gaps in the data along the outer coast occurred when the instrument was out of the water for routine maintenance 
Flow in the bay during all upwelling events was equatorward at the surface and either poleward or slowly equatorward near the bottom (Fig. 2C), reflecting the presence of the deep recirculation feature described by Roughan et al. (2005). Flow in the bay during all relaxation events was poleward throughout the water column.

Along the open coast, currents were faster and more variable, especially at the surface, reflecting the stronger influence of diurnal wind forcing than in the bay (Fig. 2D). Winds relaxed or reversed with a diurnal periodicity in addition to the mixed semidiurnal periodicity of the tidal cycle. During all cruises, flow throughout the water column was largely poleward, regardless of oceanographic condition.

\section{Species composition}

Twenty-eight taxa of crustacean larvae were collected during the present study, but 3 taxa composed $79.5 \%$ of all larvae collected (Table 1). Balanus crena- tus was the most abundant species collected (52.1\%) with a mean $( \pm \mathrm{SE})$ of $41.0 \pm 11.1$ per sampling trip followed by Chthamalus spp. (13.7\%) and pinnotherids $(13.7 \%)$, with means of $11.3 \pm 5.8$ and $11.3 \pm 4.1$, respectively.

\section{Larval community structure}

NMDS revealed structure in the larval community over time $(2 \mathrm{D}$ stress $=0.12$; Fig. 3A), which varied slightly over upwelling and relaxation cycles as reflected in the low ANOSIM test statistic (ANOSIM, wind condition, $\mathrm{R}=0.24, \mathrm{p}=0.004)$. NMDS also revealed significant structure in the larval community (2D stress $=0.03$; Fig. 3B), which was strongly separated by depth with little difference between sites (depth, $\mathrm{R}=0.77, \mathrm{p}=0.001$; site, $\mathrm{R}=0.32, \mathrm{p}=0.06$ ). The larval community at the surface and bottom were closely related at both sites and were very different than the community in the neuston.

Table 1. Taxa of crustacean larvae collected within $1 \mathrm{~km}$ from shore and in the lee of Bodega Head, California, USA, during 8 cruises from 5 June to 5 August 2005. The number of larval stages, total number of larvae collected, mean number of larvae per trip $( \pm 1 \mathrm{SE}, \mathrm{n}=8)$ and percentage of the total density of larvae collected are reported

\begin{tabular}{|c|c|c|c|c|c|}
\hline Family & Taxon & No. stages & Total $\left(\mathrm{m}^{-3}\right)$ & Mean trip ${ }^{-1}$ & Total (\%) \\
\hline \multirow[t]{9}{*}{ Cirripedia } & Balanus crenatus & 6 & 5730.0 & $41.0 \pm 11.1$ & 52.1 \\
\hline & Chthamalus spp. & 6 & 1500.9 & $11.3 \pm 5.8$ & 13.7 \\
\hline & Balanus glandula & 6 & 365.0 & $2.6 \pm 0.6$ & 3.3 \\
\hline & Balanus nubilus & 6 & 111.9 & $0.9 \pm 0.4$ & 1.0 \\
\hline & Semibalanus cariosus & 6 & 17.1 & $0.1 \pm 0.1$ & 0.2 \\
\hline & Pollicipes polymerus ${ }^{\mathrm{a}}$ & 6 & 8.8 & $0.1 \pm 0.03$ & 0.1 \\
\hline & Lepas spp. & 6 & 3.6 & $0.1 \pm 0.02$ & 0.03 \\
\hline & Solidobalanus hesperius ${ }^{\mathrm{a}}$ & 6 & 3.3 & $0.1 \pm 0.2$ & 0.03 \\
\hline & Balanus balanus ${ }^{\mathrm{a}}$ & 6 & 0.8 & $0.1 \pm 0.01$ & 0.01 \\
\hline Thalassinidea & Neotrypaea californiensis & 5 & 236.3 & $1.8 \pm 0.7$ & 2.2 \\
\hline Hippidae & Emerita analoga & 6 & 142.0 & $1.1 \pm 0.5$ & 1.3 \\
\hline \multirow[t]{2}{*}{ Paguroidea } & Pagurus spp. & 5 & 183.4 & $1.4 \pm 0.8$ & 1.7 \\
\hline & Pagurid & 5 & 38.3 & $0.3 \pm 0.1$ & 0.4 \\
\hline \multirow[t]{2}{*}{ Porcellanidae } & Pachycheles spp. ${ }^{\mathrm{b}}$ & 3 & 374.7 & $2.8 \pm 1.0$ & 3.4 \\
\hline & Petrolisthes spp. ${ }^{\mathrm{b}}$ & 3 & 71.3 & $0.5 \pm 0.1$ & 0.7 \\
\hline Pinnotheridae & Pinnotheridae & 6 & 1501.7 & $11.3 \pm 4.1$ & 13.7 \\
\hline \multirow[t]{4}{*}{ Majidae } & Pugettia richii ${ }^{\mathrm{b}}$ & 3 & 57.8 & $0.4 \pm 0.3$ & 0.8 \\
\hline & Mimulus foliatus ${ }^{\mathrm{b}}$ & 3 & 26.9 & $0.2 \pm 0.1$ & 0.8 \\
\hline & Pugettia producta ${ }^{\mathrm{b}}$ & 3 & 23.5 & $0.2 \pm 0.1$ & 0.4 \\
\hline & Scyra acutifrons ${ }^{\mathrm{b}}$ & 3 & 18.6 & $0.1 \pm 0.1$ & 0.4 \\
\hline \multirow[t]{2}{*}{ Grapsidae } & Hemigrapsus spp. & 6 & 214.0 & $1.6 \pm 0.5$ & 2.0 \\
\hline & Pachygrapsus crassipes & 6 & 53.5 & $0.4 \pm 0.2$ & 0.5 \\
\hline Portunidae & Carcinus maenus ${ }^{\mathrm{a}}$ & 6 & 5.2 & $0.1 \pm 0.04$ & 0.1 \\
\hline Xanthidae & Lophopanopeus bellus & 5 & 130.4 & $1 \pm 0.3$ & 1.2 \\
\hline \multirow[t]{4}{*}{ Cancridae } & Cancer antennarius & 6 & 137.9 & $1 \pm 0.3$ & 1.3 \\
\hline & Cancer magister & 6 & 16.1 & $0.1 \pm 0.1$ & 0.2 \\
\hline & Cancer oregonensis ${ }^{b}$ & 6 & 8.9 & $0.1 \pm 0.4$ & 0.1 \\
\hline & Cancer productus ${ }^{\mathrm{b}}$ & 6 & 9.3 & $0.1 \pm 0.03$ & 0.1 \\
\hline \multicolumn{6}{|c|}{${ }^{\mathrm{a}}$ Taxa that were too few for analysis } \\
\hline
\end{tabular}



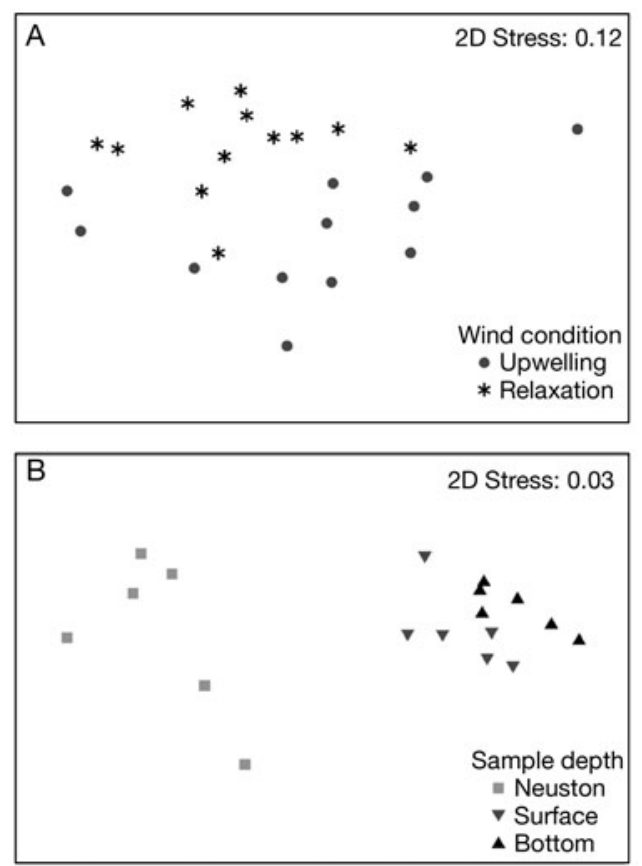

Fig. 3. Larval community patterns from non-metric multidimensional scaling. (A) Data from each sampling date were averaged by site and depth $(\mathrm{n}=24)$ and coded by upwelling-relaxation cycles. (B) Data from each site and depth $(n=18)$ were averaged across dates and were coded by sample depth

\section{Larval abundance in the lee of the headland and on the open coast}

Of the 20 taxa analyzed, pinnotherids were more abundant in the lee of Bodega Head than on the open coast, 6 taxa were more abundant on the open coast and the remaining taxa were evenly distributed throughout the study area (Table 2, Figs. 4-6, Table A1 in Appendix 1). The site by larval stage interaction term of the 2-way ANOVA was not significant for any taxon, with the exception of porcellanids (marginally significant; Table A1).

The relative abundance of larval stages in the lee of the headland and on the open coast indicated that 9 of the 20 taxa were released nearshore and remained there throughout development (Table 2, Figs. 4 \& 5). Although early larval stages of barnacles passed through our nets, later stages of 4 of 6 taxa (Balanus crenatus, B. glandula, B. nubilus and Chthamalus spp.) occurred in high concentrations (Fig. 4). Larval stages of the other 2 species of barnacles were only present as postlarvae, presumably because their reproductive seasons had concluded well in advance of the present study (Morris et al. 1980, Strathmann 1987). All larval stages of 3 taxa of decapod crustaceans (pinnotherids, Pagurus spp. and pagurids) were abundant as early stage larvae and steadily declined during development

Table 2. Horizontal and vertical distributions of 20 taxa of crustacean larvae collected within $1 \mathrm{~km}$ from shore and in the lee of Bodega Head, California, from 15 June to 5 August 2005. Nine taxa were prevalent nearshore throughout development, 9 were prevalent only as first stage larvae and postlarvae, and dispersal patterns could not be determined for 2 taxa. Remaining categories summarize ANOVA, Student's $t$-test and Tukey HSD results (Tables A1-A3 in Appendix 1); p < 0.05; ns: not significant. Pinnotherids were more abundant in the bay, and 6 taxa were more abundant outside the bay. Nine taxa were most prevalent near the bottom, 9 taxa did not occur in the neuston and Lepas spp. postlarvae were most common in the neuston. Two taxa undertook ontogenetic vertical migrations (OVM) and 13 undertook diel vertical migrations (DVM)

\begin{tabular}{|c|c|c|c|c|c|}
\hline Taxon & Dispersal & Site & Mean depth & OVM & DVM \\
\hline Balanus crenatus & Nearshore & Outside & Bottom & None & ns \\
\hline Balanus glandula & Nearshore & ns & Bottom & Reverse & ns \\
\hline Balanus nubilus & Nearshore & ns & Bottom & None & ns \\
\hline Chthamalus spp. & Nearshore & ns & Avoid neuston & None & ns \\
\hline Pinnotheridae & Nearshore & Inside & Bottom & None & ns \\
\hline Pagurus spp. & Nearshore & ns & Avoid neuston & Classic & Yes \\
\hline Pagurid & Nearshore & Outside & Bottom & None & Yes \\
\hline Hemigrapsus spp. & Nearshore & ns & Avoid neuston & None & Yes \\
\hline Porcellanidae & Nearshore & Outside & Avoid neuston & None & Yes \\
\hline Neotrypaea californiensis & Offshore migration & ns & Bottom & Unknown & Yes \\
\hline Emerita analoga & Offshore migration & ns & Avoid neuston & Unknown & Yes \\
\hline Pachygrapsus crassipes & Offshore migration & ns & ns & Unknown & Yes \\
\hline Mimulus foliatus/ Pugettia richii & Offshore migration & Outside & Avoid neuston & Unknown & Yes \\
\hline Scyra acutifrons/ Pugettia producta & Offshore migration & ns & Avoid neuston & Unknown & Yes \\
\hline Lophopanopeus bellus & Offshore migration & ns & Bottom & Unknown & Yes \\
\hline Cancer antennarius & Offshore migration & Outside & Bottom & Unknown & Yes \\
\hline Cancer magister & Offshore migration & ns & Avoid neuston & Unknown & Yes \\
\hline Cancer oregonensis/productus & Offshore migration & ns & Avoid neuston & Unknown & Yes \\
\hline Lepas spp. & Unknown & Outside & Neuston & Unknown & Unknown \\
\hline Semibalanus cariosus & Unknown & ns & Bottom & Unknown & ns \\
\hline
\end{tabular}



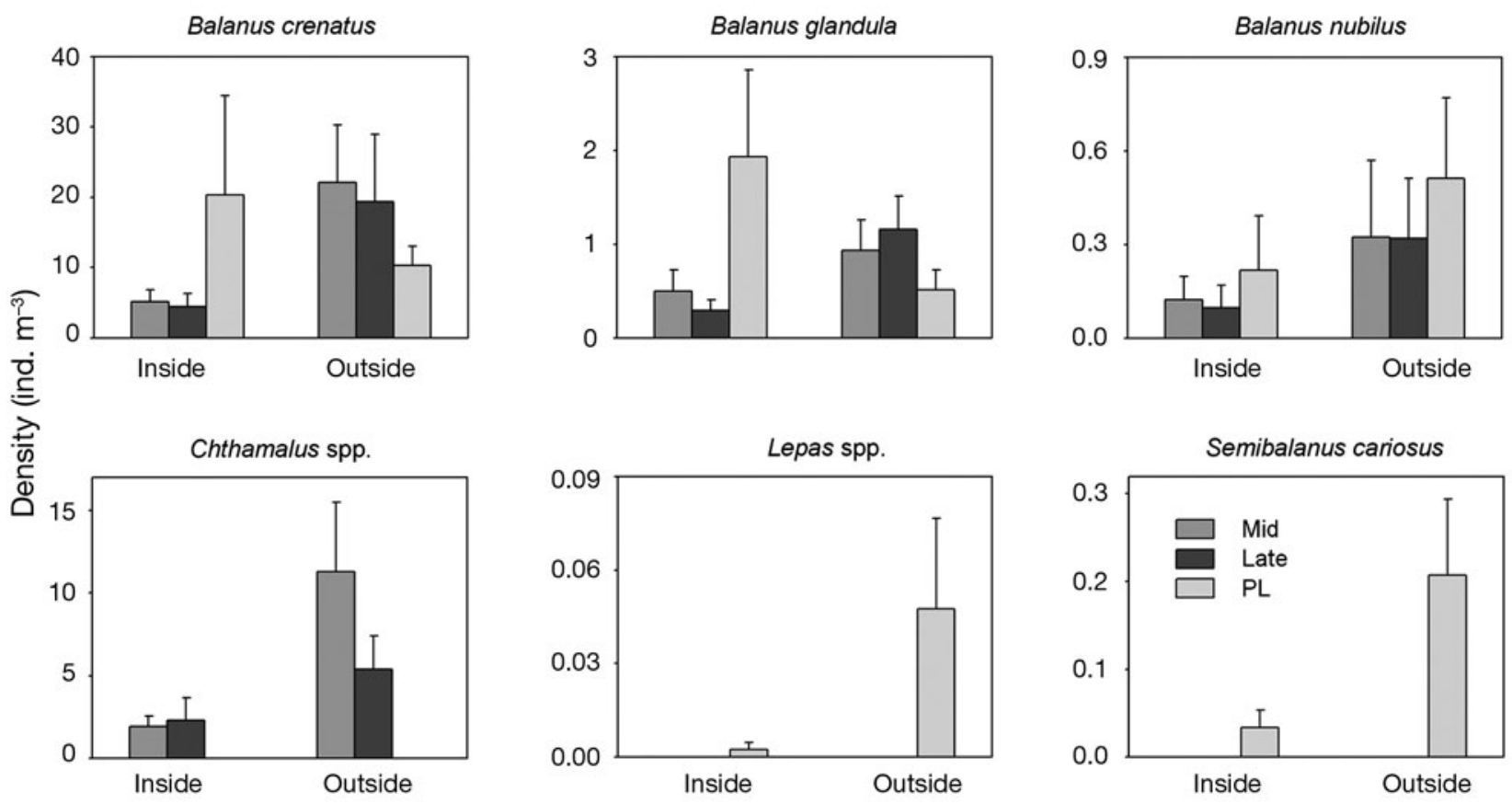

Fig. 4. Mean density (+1 SE) of 6 taxa of barnacles by larval stage inside Bodega Bay, California, and within $1 \mathrm{~km}$ from shore (outside). Early stage barnacle larvae passed through the plankton nets, but mid and late larval stages and postlarvae (PL) were prevalent
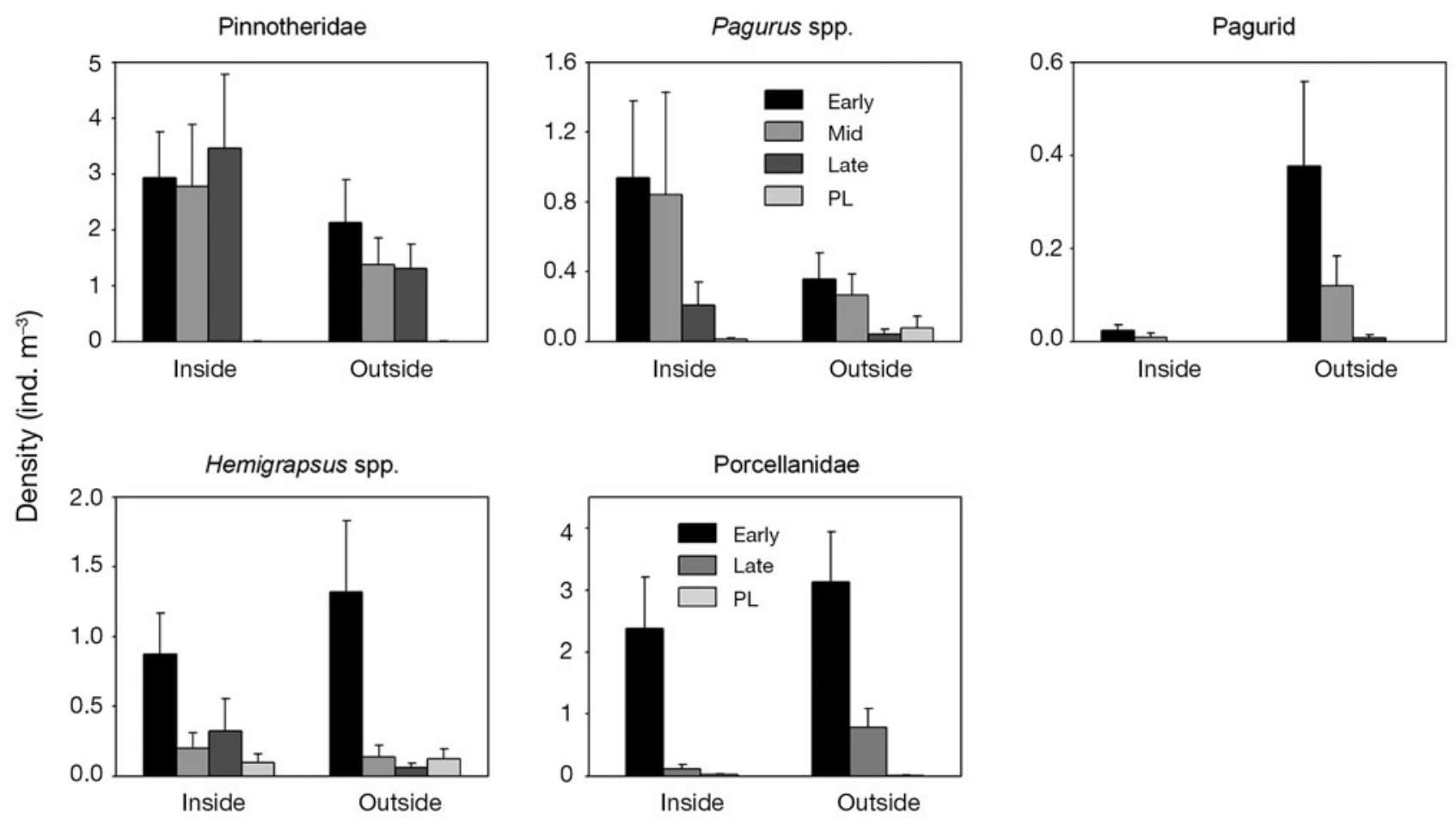

Fig. 5. Mean larval density (+1 SE) of 5 taxa of decapod crustaceans that were prevalent after release and gradually declined during development inside Bodega Bay, California, and within $1 \mathrm{~km}$ from shore (outside). Larvae were combined into early, mid, late and postlarval (PL) stages to simplify presentation. Porcellanids only have 2 larval stages: early and late 

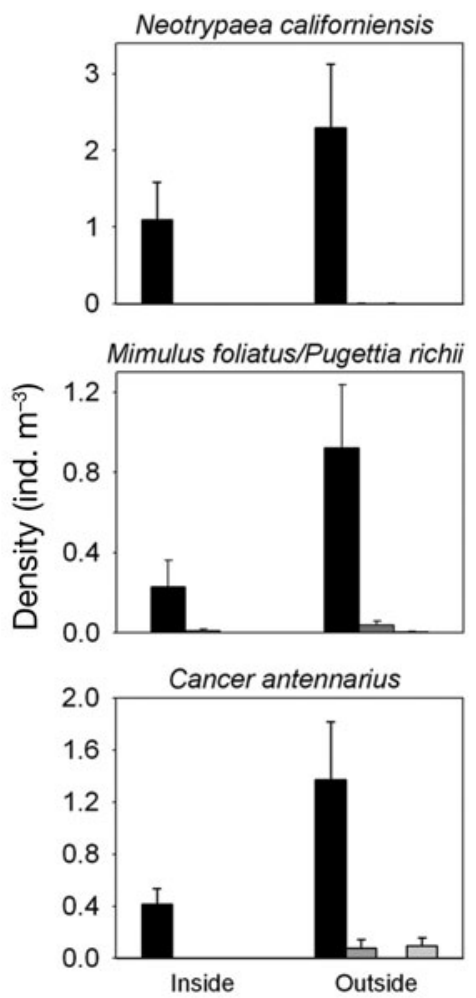
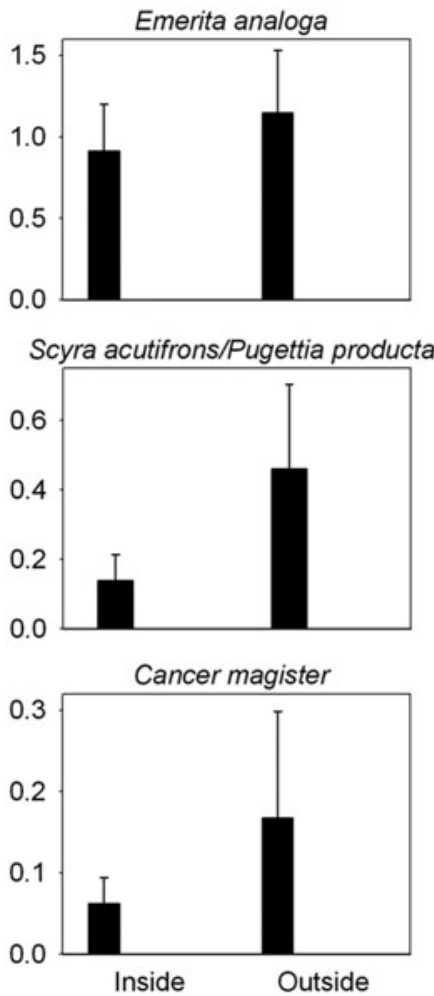
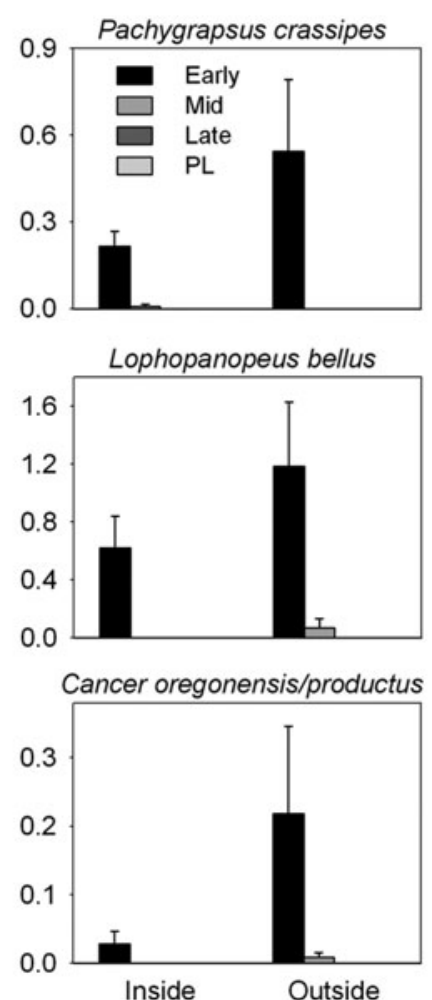

Fig. 6. Mean larval density (+1 SE) of 9 taxa of decapod crustaceans that were prevalent only as early stage larvae or postlarvae (PL) inside Bodega Bay, California, and within $1 \mathrm{~km}$ from shore (outside). Majids (Mimulus foliates/Pugettia richii and Scyra acutifrons/Pugettia producta) have only 2 larval stages: early and late

due to mortality (Fig. 5). The steeper decreases of 2 other taxa of decapods (Hemigrapsus spp., porcellanids) between early and later stages was greater than that expected due to mortality (J. W. White et al. unpubl. data), suggesting that more of these larvae were transported from the study area (Fig. 5). Larvae of the 9 remaining taxa of decapods (Neotrypaea californiensis, Emerita analoga, Pachygrapsus crassipes, Mimulus foliatus/Pugettia richii, Scyra acutifrons/ Pugettia producta, Lophopanopeus bellus and all Cancer spp.) were abundant in the lee of the headland and on the open coast as early stage larvae and later stages were absent or uncommon, indicating that larvae migrated offshore after hatching (Table 2, Fig. 6).

\section{Larval depth distributions}

Larvae of 19 of 20 taxa were non-randomly distributed in the water column during the daytime (Tables 2 \& A2, Figs. 7-9). Larvae of 9 taxa were most prevalent in the lower water column. Four of 6 barnacle taxa were most common in bottom waters (Balanus crenatus, B. glandula, B. nubilus and Semibalanus cariosus), and the remaining 5 taxa that were concentrated in bottom waters were pinnotherids, pagurids, Neotrypaea californiensis, Lophopanopeus bellus and Cancer antennarius. Nine taxa were uncommon in the neuston (Chthamalus spp., Pagurus spp., Hemigrapsus spp., porcellanids, Emerita analoga, both majid taxa, Cancer magister and Cancer oregonensis / Cancer productus). Lepas spp. postlarvae were most common in the neuston and Pachygrapsus crassipes larvae were distributed throughout the water column.

Few ontogenetic vertical migrations were evident (Tables 2 \& A2, Figs. 7-9). Larvae of Balanus glandula occurred low in the water column, whereas postlarvae occurred in the neuston, indicating a reverse ontogenetic vertical migration (Fig. 7). Lepas spp. postlarvae only occurred in the neuston and may undertake a reverse vertical migration, presuming that larvae remain deeper in the water column as did those of the other 5 species of barnacles. Early stage larvae of Pagurus spp. were more common higher in the water column than were mid-stage larvae and postlarvae, indicating a classic ontogenetic vertical migration (Fig. 8). There were significant depth by stage interactions for 6 other taxa, but there was no clear trend in changing depth distributions throughout development for these taxa (Table A2). 

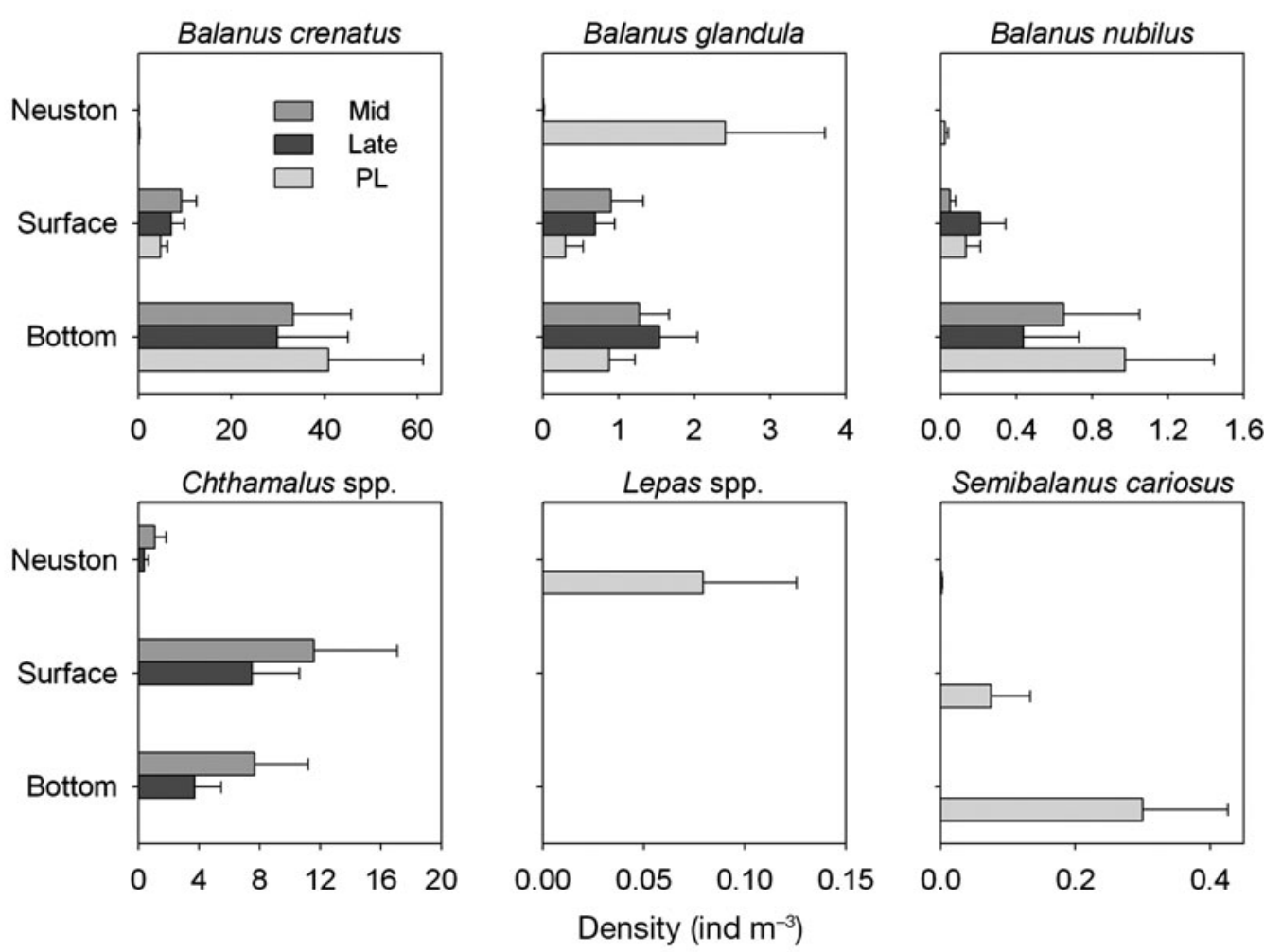

Fig. 7. Mean larval density (+1 SE) in the neuston, surface and bottom of the water column by larval stage during the daytime for 6 taxa of barnacles. Larvae were collected inside Bodega Bay, California, and within $1 \mathrm{~km}$ from shore. Early stage barnacle larvae passed through plankton nets but mid, late and postlarval (PL) stages were prevalent

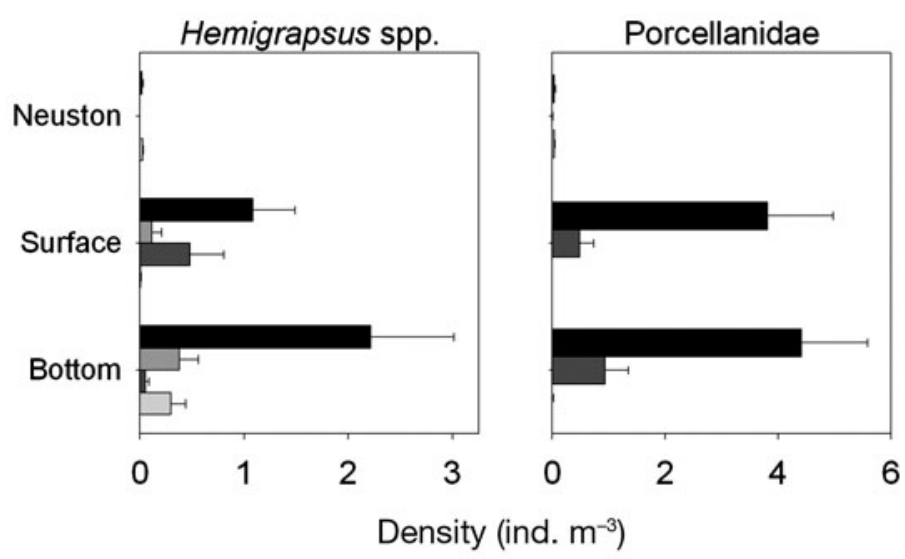

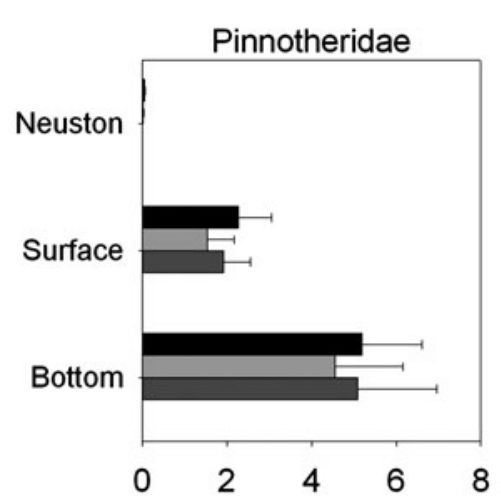

Pagurus spp.
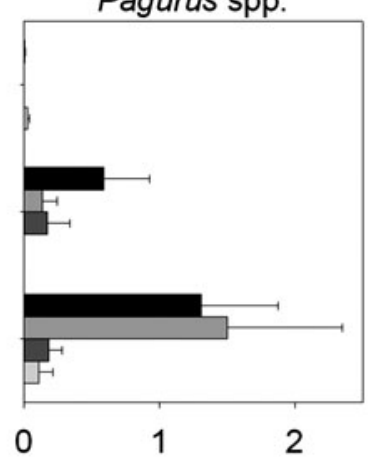

0

2 vae passed through plankton nets but mid, late and postlarval (PL) stages were prevalent 
Pinnotherid larvae and all barnacle taxa except Lepas spp. primarily occurred deep in the water column throughout the day and night (Tables 2 \& A3, Fig. 10). In contrast, diel vertical migrations were evident for larvae of the 13 remaining taxa for which tests were possible, as revealed by significant depth by day-night interactions (Table A3).

\section{DISCUSSION}

\section{Are larval concentrations greater in the lee of the headland than on the open coast?}

Crustacean larvae occurred in high concentrations both in the lee of the small headland and within $1 \mathrm{~km}$ from shore. Larvae of 6 of the 20 taxa were more common on the open coast, whereas larvae of only 1 taxon (pinnotherids) were more prevalent in the lee of Bodega Head. High concentrations of crustacean lar- vae and postlarvae previously were found close to shore in cross-shelf surveys in our region (Morgan et al. 2009c). A large majority (98\%) of 23 species of crustacean larvae were highly concentrated within $1 \mathrm{~km}$ of the headland and were still abundant in all stages of development $6 \mathrm{~km}$ from shore before markedly declining thereafter (Morgan et al. 2009c). Larvae were concentrated in a coastal boundary layer of reduced offshore Ekman transport and slow alongshore currents <10 km from shore (Lentz \& Chapman 1989, Largier et al. 1993, Kaplan \& Largier 2006). This characteristic feature of shoreline circulation (Pettigrew \& Murray 1986, Shanks 1995) has been repeatedly observed in our region in high frequency radar maps of surface currents, and it likely contributes to the retention of diverse crustacean larvae close to shore in our region as well as the weaker upwelling conditions along the coasts of Oregon (Peterson et al. 1979, Shanks \& Shearman 2009) and central and southern California (Grantham 1997, Tapia \& Pineda 2007).

The abundance of larvae close to shore along the exposed coast provides a ready pool of larvae to be entrained into the recirculation feature in the lee of Bodega Head. Although we previously found that recruitment was greater in the recirculation feature than on the exposed coast of the headland (Mace \& Morgan 2006a), we found little evidence that larvae and postlarvae of most species were more concentrated in the lee of the headland during our plankton survey. We designed our survey based on the prevailing idea that larvae would usually be more abundant in the lee of headlands than on the open coast, regardless of oceanographic conditions (Roughgarden et al. 1988, Wing et al. 1995, 1998). However, the unexpectedly high concentration of larvae along the open coast led to our inability to detect this difference by averaging samples collected over upwelling-relaxation cycles. If larvae are entrained into the recirculation feature only while upwelling winds persist, then greater average concentrations of larvae in the lee of the headland would not be detected against the backdrop of high concentrations already present along the open coast. In addition, larval concentrations of some species can be more abundant during relaxation conditions, when a poleward boundary
Fig. 9. Mean larval density ( $+1 \mathrm{SE}$ ) in the neuston, surface and bottom of the water column by larval stage during the daytime for 9 taxa of decapod crustaceans that were prevalent only as early stage larvae. Larvae were collected inside Bodega Bay, California, and within $1 \mathrm{~km}$ from shore 

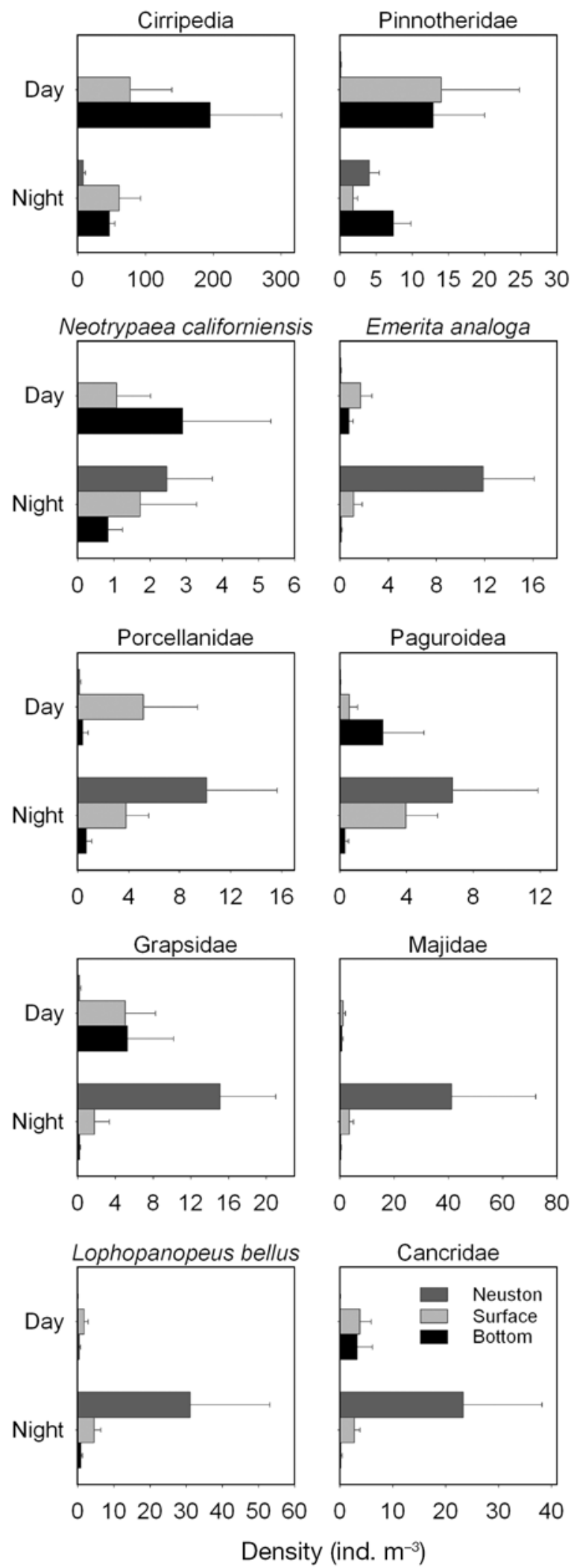

Fig. 10. Depth distributions of 10 taxa of crustacean larvae that were collected during the day and night inside Bodega Bay, California, and within $1 \mathrm{~km}$ from shore current delivers larvae to Bodega Bay and the open coast from as far as the upwelling shadow in the lee of Point Reyes (Wing et al. 1995, 1998, 2003, Roughan et al. 2005). During the present study, the NMDS detected differences in the larval community over time, although the separation in the larval community between upwelling and relaxation was not very distinct (ANOSIM, $\mathrm{R}=0.24$ ). Because larvae can be transported to the lee of Bodega Head during both upwelling and relaxation conditions, larvae would need to be sampled frequently for weeks to determine whether most species are entrained into the recirculation feature from the coastal boundary layer during upwelling conditions and persist there after upwelling relaxes.

Although equatorward winds prevail during the peak upwelling season in the region, the present study was conducted during a year of weak upwelling characterized by more frequent relaxation events of longer duration (Morgan et al. 2009a). Upwelling during the present study was only $107.9 \pm 10.7 \mathrm{~m}^{3} \mathrm{~s}^{-1} 100 \mathrm{~m}^{-1}$ coastline in an area where it typically ranges between 100 to $200 \mathrm{~m}^{3} \mathrm{~s}^{-1} 100 \mathrm{~m}^{-1}$ coastline (Morgan et al. 2009b,c). Consequently, larvae may have been entrained in the lee of Bodega Head less often and for shorter durations than usual, contributing to the lower concentrations of larvae in the lee of the headland than expected.

\section{Do larvae of some species complete development nearshore while others migrate offshore?}

About half of the taxa appeared to complete development nearshore, while the other half apparently migrated offshore, which is largely consistent with the results of our cross-shelf larval surveys (Morgan et al. 2009a,c). All larval stages were highly concentrated close to shore in both studies for 6 taxa (Balanus crenatus, B. glandula, Chthamalus spp., pinnotherids, Pagurus spp. and pagurids) and for B. glandula in the weak upwelling off southern California (Tapia \& Pineda 2007). In both of our studies, mid to late stage larvae of these taxa were almost as abundant as early stage larvae. This also is reflected in the lower larval mortality rates of mid to late stage than early stage larvae (J. W. White et al. unpubl. data). The steeper declines through development for the other 2 taxa in this group (Hemigrapsus spp. and porcellanids) are consistent with later stages ranging farther from shore in the cross-shelf surveys (Morgan et al. 2009c). All larval stages of $B$. nubilus were collected nearshore during this study, but later stages occurred over the outershelf during the cross-shelf surveys (Morgan et al. 2009c). Nine taxa were only prevalent as early stages or postlarvae in the present study (Neotrypaea cali- 
forniensis, Emerita analoga, Pachygrapsus crassipes, 2 taxa of majids, Lophopanopeus bellus and 3 taxa of cancrids), which is consistent with later stages occurring offshore in the cross-shelf surveys (Morgan et al. 2009c). The only exception is $N$. californiensis, which largely completed development nearshore in the crossshelf survey (Morgan et al. 2009c). This species primarily reproduces in June and July (Morris et al. 1980), and larvae may not have had sufficient time to develop to later stages if the reproductive season occurred later than during our previous study.

\section{Does larval behavior facilitate nearshore retention and cross-shelf migration?}

Distinctive vertical distributions of larvae may contribute to interspecific differences in the relative abundance of larval stages nearshore. Barnacle (Balanus crentuts, B. glandula and B. nubilus) and pinnotherid larvae occurred nearshore in high concentrations by remaining in bottom waters throughout development and throughout the day. Remaining deep in the water column would keep larvae close to shore throughout development, where slow onshore and poleward net transport occurs during prevailing upwelling conditions along the open coast off Bodega Head (Morgan et al. 2009c). B. glandula appeared to undertake a reverse ontogenetic vertical migration wherein larvae occurred close to shore by remaining deep in the water column and postlarvae rose into the neuston where winds and internal waves may facilitate onshore recruitment (Pineda 1999, Shanks 2009).

Pagurus spp. larvae also occurred nearshore at relatively high concentrations throughout development by using a different suite of behaviors. Early stage larvae occurred higher in the water column than the barnacles and pinnotherids, while still avoiding the shallow Ekman layer. Larvae then undertook a classic ontogenetic vertical migration, wherein later larval stages occurred deeper in the water column than early stage larvae. As a consequence, nearshore retention would strengthen during larval development. Early stage larvae would not spend as much time in shorewardflowing bottom waters as the barnacles and pinnotherids. However, by undertaking diel vertical migrations, larvae would still not be transported far from shore, because they only ascended into the Ekman layer at night when surface currents weakened or reversed (Peterson 1998, Batchelder et al. 2002; Fig. 2D).

Four taxa primarily occurred in bottom waters and appeared to undertake diel vertical migrations. Ontogenetic vertical migrations were not apparent for the pagurid and could not be determined for Neotrypaea californiensis, Lophopanoperus bellus and Cancer antennarius since only first stage larvae were collected. Undertaking diel vertical migrations may not keep larvae of these taxa as close to shore as for the previous taxa. Cross-shelf surveys off Bodega Head revealed that all larval stages of these taxa commonly occurred close to shore while later larval stages of the pagurid, C. antennarius and L. bellus ranged farther from shore (Morgan et al. 2009c). However, N. californiensis larvae completed development nearshore by occurring deep in the water column during the crossshelf surveys (Morgan et al. 2009c).

Nine taxa were not as concentrated in bottom waters, appeared to undertake diel vertical migrations and did not appear to undertake ontogenetic vertical migrations. Eight of these taxa occurred near the surface while avoiding the neuston while 1 taxon did not avoid the neuston (Pachygrapsus crassipes). Larvae of 3 taxa (Chthamalus spp., Hemigrapsus spp. and porcellanids) did not appear to undertake ontogenetic vertical migrations, although Chthamalus spp. postlarvae previously have been reported to be abundant in the neuston (Pineda 1999). The larger proportion of larvae occurring nearer to the surface increased the probability that larvae would not complete development close to shore. The 5 taxa that primarily were present as first stage larvae in this group (Pachygrapsus crassipes, Mimulus foliatus/Pugettia richii, Scyra acutifrons/Pugettia producta, Cancer magister and Cancer oregonensis/Cancer productus) ranged well onto the shelf later in development during previous cross-shelf surveys (Morgan et al. 2009c). Of the 3 taxa that occurred nearshore in this group throughout development, 2 declined precipitously after the first larval stage (porcellanids and Hemigrapsus spp.), which is also consistent with later larval stages ranging farther onto the shelf; only Chthamalus spp. occurred in high concentrations nearshore later in development. The relative abundance of larvae observed nearshore for this group was largely consistent with cross-shelf distributions of larvae.

Larval behavior appears to determine whether larvae typically complete development nearshore or migrate offshore later in development. The relative abundance of larval stages nearshore largely matched the vertical distributions of larvae during the present study and usually were consistent with those determined in cross-shelf surveys at this study site (Morgan et al. 2009a,c). Interspecific differences in mean depth distributions and apparent ontogenetic and diel vertical migrations may collectively contribute to interspecific differences in cross-shelf transport. Passive larval advection and diffusion alone cannot account for the interspecific differences in the relative abundances of larval stages observed during the present study or the 
cross-shelf distributions observed previously both at this study site and the weaker upwelling regime off Oregon (Lough 1974, Morgan et al. 2009a,c, Shanks \& Shearman 2009). Larvae of these species all hatch nearshore and develop concurrently, being subject to the same physical processes. Moreover, larval behavior must mediate cross-shelf transport, because different stages of the same species are being transported in opposite directions at the same time; larvae are transported from shore while postlarvae return to shore (Morgan 2006, Morgan et al. 2009c). Natural selection may have favored simple larval behaviors that exploit conservative circulation patterns, enabling larvae of different species to remain nearshore or be transported various distances offshore while limiting alongshore displacement across species ranges (Strathmann et al. 2002, Shanks \& Eckert 2005, Morgan 2006, Morgan \& Anastasia 2008, Morgan et al. 2009c). Circulation in upwelling regions is fundamentally similar worldwide, which may enable zooplankton to minimize losses from advection (Peterson 1998).

\section{Implications for communities along upwelling coasts}

The recirculation feature in the lee of Bodega Head previously has been reported to be a recruitment hotspot (Roughan et al. 2005, Mace \& Morgan 2006a), but the present study demonstrates that larvae of a wide variety of taxa are at least as abundant along the open coast in this region of strong upwelling. Although larval retention in upwelling regions is widely thought to be restricted to bays and upwelling shadows in the lee of headlands (Wing et al. 1995, Graham \& Largier 1997, Lagos et al. 2005, Roughan et al. 2005), the present study adds to the growing evidence that larval retention occurs along the open coast (Marliave 1986, Poulin et al. 2002, Tapia \& Pineda 2007, Morgan et al. 2009a,c, Shanks \& Shearman 2009). We conclude that larval retention may be more widespread in upwelling regions than is widely believed. As a consequence, larvae are more likely to recruit closer to natal populations and in higher abundance than is generally realized, which has profound implications for the ecology, evolution and management of species inhabiting upwelling coasts (Strathmann et al. 2002, Sotka et al. 2004, Shanks \& Eckert 2005, Becker et al. 2007 , Pfeiffer-Herbert et al. 2007).

This conclusion raises a question of fundamental importance to our understanding of the dynamics and structure of marine populations and communities: If the vast majority of larvae remain close to shore in areas of strong upwelling, then why are populations limited by the number of recruiting postlarvae? It is becoming increasingly apparent that larvae of most species in upwelling regions are neither passively advected far offshore (Poulin et al. 2002, Queiroga et al. 2006, Tapia \& Pineda 2007, dos Santos et al. 2008, Morgan et al. 2009a,c, Shanks \& Shearman 2009) nor limited to recruiting during infrequent relaxation conditions or years of weak upwelling (Mace \& Morgan 2006b, Jacinto \& Cruz 2008, Shanks 2009, Morgan et al. 2009b). Our 5 yr study at Bodega Head has revealed that recruitment depends on interspecific differences in the interaction of the depth of recruitment and the coincidence of larval availability with the occurrence of onshore winds, large waves, upwelled bottom water, relaxation and downwelling events and internal tides (Morgan et al. 2009b). An emerging possibility is that larvae have difficulty crossing the surf zone (Rilov et al. 2008, Shanks et al. in press).

The process responsible for observed spatial patterns in larval recruitment and adult densities in upwelling regions (Roughgarden et al. 1988, Connolly et al. 2001, Menge et al. 2004) remains elusive. New comprehensive studies are needed to investigate the coupling of larval abundance in the plankton with settlement and post-settlement mortality on the shore for diverse taxa and locations across upwelling coasts to determine the underlying mechanisms responsible for the observed spatial and temporal patterns of recruitment. Such investigations are essential for further advancing our understanding of processes that regulate marine populations and communities as well as the evolution of life in the sea (Strathmann et al. 2002, Shanks \& Eckert 2005).

Acknowledgements. We thank the captain of the RV 'Mussel Point', S. McAfee, for assistance in planning and conducting cruises. S. Miller, L. Katz, M. Sheridan, H. Carson and T. Clohessey assisted with field sampling and sample processing. This research was funded by the National Science Foundation (OCE-0326110).

\section{LITERATURE CITED}

Batchelder HP, Edwards CA, Powell TM (2002) Individualbased models of copepod populations in coastal upwelling regions: implications of physiologically and environmentally influenced diel vertical migration on demographic success and nearshore retention. Prog Oceanogr 53: 307-333

> Becker BJ, Levin LA, Fodrie FJ, McMillan PA (2007) Complex larval connectivity patterns among marine invertebrate populations. Proc Natl Acad Sci USA 104:3267-3272

Broitman BR, Navarrete SA, Smith F, Gaines SD (2001) Geographic variation of southeastern Pacific intertidal communities. Mar Ecol Prog Ser 224:21-34

Clark KR, Warwick RM (2001) Change in marine communities: an approach to statistical analysis and interpretation, 2nd edn. Natural Environment Research Council, Plymouth Marine Laboratory, Plymouth

Connolly SR, Menge BA, Roughgarden J (2001) A latitudinal 
gradient in recruitment of intertidal invertebrates in the northeast Pacific Ocean. Ecology 82:1799-1813

Dorman CE, Dever EP, Largier J, Koraãin D (2006) Buoy measured wind, wind stress and wind stress curl over the shelf off Bodega Bay, California. Deep-Sea Res II 53:2850-2864

dos Santos A, Santos AMP, Conway DVP, Bartilotti C, Lourenço P, Queiroga H (2008) Diel vertical migration of decapod larvae in the Portuguese coastal upwelling ecosystem: implications for offshore transport. Mar Ecol Prog Ser 359:171-183

Farrell TM, Bracher D, Roughgarden J (1991) Cross-shelf transport causes recruitment to intertidal populations in central California. Limnol Oceanogr 36:279-288

> Graham WM, Largier JL (1997) Upwelling shadows as nearshore retention sites: the example of northern Monterey Bay. Cont Shelf Res 17:509-532

Grantham BA (1997) Coastal upwelling, larval recruitment, and the dynamics of upper intertidal barnacle communities. PhD dissertation, Stanford University, Stanford, CA

Hickey B (1998) Coastal oceanography of western North America from the tip of Baja California to Vancouver Island. In: Robinson A, Brink KH (eds) The sea: ideas and observations on progress in the study of the seas. John Wiley \& Sons, New York

> Hobbs RC, Botsford LW, Thomas A (1992) Influence of hydrographic conditions and wind forcing on the distribution and abundance of Dungeness crab, Cancer magister, larvae. Can J Fish Aquat Sci 49:1379-1388

> Jacinto D, Cruz T (2008) Tidal settlement of the intertidal barnacles Chthamalus spp. in SW Portugal: interaction between diel and semi-lunar cycles. Mar Ecol Prog Ser 366:129-135

Kaplan DM, Largier JL (2006) HF radar-derived origin and destination of surface waters off Bodega Bay, California. Deep-Sea Res II 53:2906-2930

Lagos NA, Navarrete SA, Véliz F, Masuero A, Castilla JC (2005) Meso-scale spatial variation in settlement and recruitment of intertidal barnacles along the coast of central Chile. Mar Ecol Prog Ser 290:165-178

Largier JL, Magnell BA, Winant CD (1993) Subtidal circulation over the northern California shelf. J Geophys Res 98: 18147-18179

Lentz SJ, Chapman DC (1989) Seasonal differences in the current and temperature variability over the northern California shelf during the Coastal Ocean Dynamics Experiment. J Geophys Res 94:12571-12592

Lough R (1974) Dynamics of crab larvae (Anomura, Brachyura) off the central Oregon coast, 1969-1971. PhD dissertation, Oregon State University, Corvallis, OR

Lundquist CJ, Botsford LW, Diehl JM, Lee T, Lockwood DR, Morgan LE, Pearson EL (2000) Effects of El Niño and La Niña on local invertebrate settlement in northern California. Rep CCOFI 41:1-10

Mace AJ, Morgan SG (2006a) Larval accumulation in the lee of a small headland: implications for the design of marine reserves. Mar Ecol Prog Ser 318:19-29

> Mace AJ, Morgan SG (2006b) Biological and physical coupling in the lee of a small headland: contrasting transport mechanisms for crab larvae in an upwelling region. Mar Ecol Prog Ser 324:185-196

Marliave JB (1986) Lack of planktonic dispersal of rocky intertidal fish larvae. Trans Am Fish Soc 115:149-154

Menge BA, Blanchette C, Raimondi P, Freidenburg T and others (2004) Species interaction strength: testing model predictions along an upwelling gradient. Ecol Monogr 74: 663-684

Morgan SG (1995) Life and death in the plankton: larval mor- tality and adaptation. In: McEdward L (ed) Ecology of marine invertebrate larvae. CRC Press, Boca Raton, FL, p 279-321

Morgan SG (2001) The larval ecology of marine communities. In: Bertness MD, Gaines SD, Hay ME (eds) Marine community ecology. Sinauer Associates, Sunderland, MA, p 159-181

Morgan SG (2006) Larval migration between the Hudson River estuary and New York Bight. In: Levinton JS, Waldman J (eds) The Hudson River Estuary. Cambridge University Press, New York, p 157-170

Morgan SG, Anastasia JR (2008) Behavioral tradeoff conserves transport while increasing the risk of predation across the ranges of marine species. Proc Natl Acad Sci USA 105:222-227

> Morgan SG, Fisher JL, Mace AJ, Akins L, Slaughter AM, Bollens SM (2009a) Cross-shelf distributions and recruitment of crab postlarvae in a region of strong upwelling. Mar Ecol Prog Ser 380:173-185

> Morgan SG, Fisher JL, Mace AJ (2009b) Larval recruitment in a region of strong, persistent upwelling and recruitment limitation. Mar Ecol Prog Ser 394:79-99

Morgan SG, Fisher JL, Miller SH, McAfee ST, Largier JL (2009c) Nearshore larval retention in a region of strong upwelling and recruitment limitation. Ecology 90: 3489-3502

Morris RH, Abbott DP, Haderlie EC (1980) Intertidal invertebrates of California. Stanford University Press, Stanford, CA

> Papastephanou KM, Bollens SM, Slaughter AM (2006) Crossshelf distribution of copepods and the role of event-scale winds in a northern California upwelling zone. Deep-Sea Res II 53:3078-3093

Peterson WT (1998) Life cycle strategies of copepods in coastal upwelling zones. J Mar Syst 15:313-326

Peterson WT, Miller CB, Hutchinson A (1979) Zonation and maintenance of copepod populations in the Oregon upwelling zone. Deep Sea Res 26:467-494

Pettigrew NR, Murray SP (1986) The coastal boundary layer and inner shelf. In: Mooers CNK (ed) Baroclinic processes on continental shelves. American Geophysical Union, Washington, DC, p 95-108

Pfeiffer-Herbert AS, McManus MA, Raimondi PT, Chao Y, Chai F (2007) Dispersal of barnacle larvae along the central California coast: a modeling study. Limnol Oceanogr 52:1559-1569

Pineda J (1999) Circulation and larval distribution in internal tidal bore warm fronts. Limnol Oceanogr 44:1400-1414

Poulin E, Palma AT, Leiva G, Narvaez D, Pacheco R, Navarrete SA, Castilla JC (2002) Avoiding offshore transport of competent larvae during upwelling events: the case of the gastropod Concholepas concholepas in central Chile. Limnol Oceanogr 47:1248-1255

Queiroga H, Blanton J (2004) Interactions between behaviour and physical forcing in the control of horizontal transport of decapod crustacean larvae. Adv Mar Biol 47:107-214

> Queiroga H, Almeida MJ, Alpuim T, Flores AAV and others (2006) Tide and wind control of megalopal supply to estuarine crab populations on the Portuguese west coast. Mar Ecol Prog Ser 307:21-36

Rilov G, Schiel DR (2006) Seascape-dependent subtidalintertidal trophic linkages. Ecology 87:731-744

Rilov G, Dudas SE, Menge BA, Grantham BA, Lubchenco J, Schiel DR (2008) The surf zone: A semi-permeable barrier to onshore recruitment of invertebrate larvae? J Exp Mar Biol Ecol 361:59-74

Roughan M, Mace AJ, Largier JL, Morgan SG, Fisher JL, 
Carter ML (2005) Subsurface recirculation and larval retention in the lee of a small headland: a variation on the upwelling shadow theme. J Geophys Res 110:C10027 doi:10.1029/2005JC002898

Roughan M, Garfield N, Largier J, Dever E, Dorman C, Peterson D, Dorman J (2006) Transport and retention in an upwelling region: the role of across-shelf structure. DeepSea Res II 53:2931-2955

Roughgarden J, Gaines S, Possingham H (1988) Recruitment dynamics in complex life cycles. Science 241:1460-1466

Roughgarden J, Pennington JT, Stoner D, Alexander S, Miller $\mathrm{K}$ (1992) Collisions of upwelling fronts with the intertidal zone: the cause of recruitment pulses in barnacle populations of central California. Acta Oecol 12:35-52

Send U, Beardsley RC, Winant CD (1987) Relaxation from upwelling in the Coastal Ocean Dynamics Experiment. J Geophys Res 92:1683-1698

Shanks AL (1995) Mechanisms of cross-shelf dispersal of larval invertebrates and fishes. In: McEdward L (ed) Ecology of marine invertebrate larvae. CRC Press, Boca Raton, FL, p 323-367

Shanks AL (2009) Barnacle settlement versus recruitment as indicators of larval delivery. II. Time-series analysis and hypothesized delivery mechanisms. Mar Ecol Prog Ser 385:217-226

Shanks AL, Eckert GL (2005) Population persistence of California Current fishes and benthic crustaceans: a marine drift paradox. Ecol Monogr 75:505-524

Shanks AL, Shearman RK (2009) Paradigm lost? Cross-shelf distributions of intertidal invertebrate larvae are unaffected by upwelling or downwelling. Mar Ecol Prog Ser 385:189-204

Shanks AL, Morgan SG, MacMahan J, Reiners AJHM (in press) Surfzone hydrodynamics as determinants of temporal and spatial variation in larval recruitment. J Exp Mar Biol Ecol

Sotka EE, Wares JP, Barth JA, Grosberg RK, Palumbi SR (2004) Strong genetic clines and geographical variation in gene flow in the rocky intertidal barnacle Balanus glandula. Mol Ecol 13:2143-2156

Sponaugle S, Cowen RK, Shanks A, Morgan SG and others
(2002) Predicting self-recruitment in marine populations: biophysical correlates and mechanisms. Bull Mar Sci 70: 341-375 Suppl

Strathmann MF (1987) Reproduction and development of marine invertebrates of the northern Pacific Coast. University of Washington Press, Seattle, WA

Strathmann R, Hughes T, Kuris A, Lindeman K, Morgan S, Pandolfi J, Warner R (2002) Evolution of local recruitment and its consequences for marine populations. Bull Mar Sci 70:377-396

Swearer SE, Shima JS, Hellberg ME, Thorrold SR and others (2002) Evidence of self-recruitment in demersal marine populations. Bull Mar Sci 70:251-271 Suppl

Tapia FJ, Pineda J (2007) Stage-specific distribution of barnacle larvae in nearshore waters: potential for limited dispersal and high mortality rates. Mar Ecol Prog Ser 342: $177-190$

Underwood AJ, Keough MJ (2001) Supply-side ecology: the nature and consequences of variations in recruitment of intertidal organisms. In: Bertness MD, Gaines SD, Hay ME (eds) Marine community ecology. Sinauer Associates, Sunderland, MA, p 183-200

Wares JP, Castañeda AE (2005) Geographic range of Chthamalus along the west coast of North America. J Mar Biol Assoc UK 85:327-331

Wing SR, Botsford L, Largier JL, Morgan LE (1995) Spatial structure of relaxation events and crab settlement in the northern California upwelling system. Mar Ecol Prog Ser 128:199-211

Wing SR, Botsford L, Ralston JSV, Largier JL (1998) Meroplanktonic distribution and circulation in a coastal retention zone of the northern California upwelling system. Limnol Oceanogr 43:1710-1721

- Wing SR, Botsford L, Morgan LE, Diehl JM, Lundquist CJ (2003) Inter-annual variability in larval supply to populations of 3 invertebrate taxa in the northern California Current. Estuar Coast Shelf Sci 57:859-872

Yoshioka PM (1982) Role of planktonic and benthic factors in the population dynamics of the bryozoan Membranipora membranacea. Ecology 63:457-468

Appendix 1. ANOVA results determining whether 20 taxa of crustacean larvae were more abundant inside Bodega Bay or on the adjacent open coast and whether they undertook diel or ontogenetic vertical migrations

Table A1. 2-way ANOVA blocked by sampling dates testing for differences in larval density inside and outside of Bodega Bay (site) among larval stages (stage). Pinnotherids were more abundant inside the bay, 6 taxa were more abundant outside the bay and the remaining taxa were evenly distributed throughout the study area. na: not applicable; ns: not significant

\begin{tabular}{|c|c|c|c|c|c|c|c|c|c|c|}
\hline \multirow[t]{2}{*}{ Taxon } & \multirow{2}{*}{$\overline{\mathrm{df}}$} & \multicolumn{2}{|c|}{ Site } & \multirow[t]{2}{*}{ Site } & \multicolumn{3}{|c|}{ Stage } & \multicolumn{3}{|c|}{ - Site $\times$ Stage } \\
\hline & & $F$ & $\mathrm{p}$ & & $\mathrm{df}$ & $F$ & $\mathrm{p}$ & $\mathrm{df}$ & $F$ & $\mathrm{p}$ \\
\hline Pinnotheridae & 1 & 5.19 & 0.02 & Inside & 2 & 0.52 & 0.6 & 3 & 0.59 & 0.55 \\
\hline Balanus crenatus & 1 & 7.09 & 0.01 & Outside & 2 & 0.45 & 0.64 & 3 & 0.82 & 0.44 \\
\hline Lepas spp. & 1 & 4.31 & 0.04 & Outside & na & na & na & na & na & na \\
\hline Porcellanidae & 1 & 4.60 & 0.03 & Outside & 2 & 44.30 & $<0.001$ & 3 & 3.02 & 0.05 \\
\hline Pagurid & 1 & 7.75 & 0.01 & Outside & 2 & 2.03 & 0.16 & 3 & 0.34 & 0.55 \\
\hline Mimulus foliatus/Pugettia richii & 1 & 7.39 & 0.01 & Outside & 1 & 21.85 & $<0.001$ & 3 & 2.86 & 0.09 \\
\hline Cancer antennarius & 1 & 6.51 & 0.01 & Outside & 2 & 63.40 & $<0.001$ & 3 & 0.33 & 0.72 \\
\hline Balanus nubilus & 1 & 0.94 & 0.34 & ns & 2 & 0.56 & 0.57 & 3 & 0.47 & 0.70 \\
\hline Balanus glandula & 1 & 1.94 & 0.17 & ns & 2 & 0.01 & 0.99 & 3 & 1.38 & 0.25 \\
\hline Chthamalus spp. & 1 & 1.65 & 0.20 & ns & 2 & 20.19 & $<0.001$ & 3 & 0.90 & 0.44 \\
\hline Semibalanus cariosus & 1 & 1.96 & 0.17 & ns & na & na & na & na & na & na \\
\hline Neotrypaea californiensis & 1 & 0.19 & 0.66 & ns & na & na & na & na & na & na \\
\hline Emerita analoga & 1 & 0.22 & 0.65 & ns & na & na & na & na & na & na \\
\hline
\end{tabular}


Table A1 (continued)

\begin{tabular}{|c|c|c|c|c|c|c|c|c|c|c|}
\hline \multirow{2}{*}{ Taxon } & \multicolumn{3}{|c|}{$\ldots$ Site- } & \multirow{2}{*}{ Site } & \multicolumn{3}{|c|}{ _ Stage -} & \multicolumn{3}{|c|}{ - Site $\times$ Stage } \\
\hline & $\mathrm{df}$ & $F$ & $\mathrm{p}$ & & df & $F$ & $\mathrm{p}$ & $\mathrm{df}$ & $F$ & $\mathrm{p}$ \\
\hline Pagurus spp. & 1 & 1.15 & 0.29 & ns & 3 & 5.40 & 0.001 & 3 & 0.26 & 0.85 \\
\hline Hemigrapsus spp. & 1 & 0.25 & 0.62 & ns & 3 & 15.77 & $<0.001$ & 3 & 0.48 & 0.69 \\
\hline Pachygrapsus crassipes & 1 & 0.02 & 0.88 & ns & na & na & na & na & na & na \\
\hline Scyra acutifrons/ Pugettia producta & 1 & 0.79 & 0.38 & ns & na & na & na & na & na & na \\
\hline Lophopanopeus bellus & 1 & 0.48 & 0.49 & ns & na & na & na & na & na & na \\
\hline Cancer magister & 1 & 0.03 & 0.88 & ns & na & na & na & na & na & na \\
\hline Cancer oregonensis/Cancer productus & 1 & 3.35 & 0.07 & ns & 1 & 16.50 & $<0.001$ & 3 & 2.23 & 0.09 \\
\hline
\end{tabular}

Table A2. 2-way ANOVA blocked by sampling dates testing for differences in larval vertical distribution (depth) among larval stages (stage). Depth by larval stage interactions indicated ontogenetic vertical migrations. Depths with different letters are significantly different $(\mathrm{p}<0.05)$ according to the Tukey HSD test. PL: postlarvae; na: not applicable; ns: not significant

\begin{tabular}{|c|c|c|c|c|c|c|c|c|c|c|}
\hline \multirow{2}{*}{ Taxon } & \multicolumn{3}{|c|}{ Depth } & \multicolumn{3}{|c|}{ Depth $\times$ Stage } & \multirow{2}{*}{ Stage } & \multicolumn{3}{|c|}{ Depth } \\
\hline & df & $F$ & $\mathrm{p}$ & $\mathrm{df}$ & $F$ & $\mathrm{p}$ & & Bottom & Surface & Neuston \\
\hline \multicolumn{11}{|l|}{ Bottom } \\
\hline Balanus crenatus & 2 & 133 & $<0.001$ & 2 & 0.06 & 0.99 & & $\mathrm{~A}$ & B & $\mathrm{C}$ \\
\hline Balanus nubilus & 2 & 8.2 & $<0.001$ & 2 & 1.12 & 0.35 & & A & B & $\mathrm{B}$ \\
\hline \multirow[t]{3}{*}{ Balanus glandula } & 2 & 19.5 & $<0.001$ & 2 & 4.59 & 0.001 & Mid & $\mathrm{A}$ & B & $\mathrm{C}$ \\
\hline & & & & & & & Late & A & $\mathrm{A}$ & B \\
\hline & & & & & & & PL & & ns & \\
\hline Semibalanus cariosus & 2 & 7.01 & 0.001 & na & na & na & & A & B & B \\
\hline Pagurid & 2 & 10.8 & $<0.001$ & 2 & 0.67 & 0.51 & & A & B & B \\
\hline Pinnotheridae & 2 & 108 & $<0.0001$ & 2 & 0.24 & 0.92 & & A & B & $\mathrm{C}$ \\
\hline Neotrypaea californiensis & 2 & 18.6 & $<0.001$ & na & na & na & & A & B & $\mathrm{C}$ \\
\hline Lophopanopeus bellus & 2 & 23.1 & $<0.001$ & na & na & na & & $\mathrm{A}$ & B & $\mathrm{C}$ \\
\hline \multirow[t]{3}{*}{ Cancer antennarius } & 2 & 24.2 & $<0.001$ & 2 & 14.4 & $<0.001$ & Early & $\mathrm{A}$ & $\mathrm{B}$ & $\mathrm{C}$ \\
\hline & & & & & & & Mid & & ns & \\
\hline & & & & & & & PL & & ns & \\
\hline \multicolumn{11}{|l|}{ Avoid neuston } \\
\hline \multirow[t]{4}{*}{ Chthamalus spp. } & 2 & 16.5 & $<0.001$ & 2 & 3.59 & 0.001 & Early & A & $\mathrm{AB}$ & B \\
\hline & & & & & & & Mid & A & $\mathrm{A}$ & B \\
\hline & & & & & & & Late & A & $\mathrm{A}$ & B \\
\hline & & & & & & & PL & & ns & \\
\hline Emerita analoga & 2 & 18.9 & $<0.001$ & na & na & na & & A & $\mathrm{A}$ & B \\
\hline \multirow[t]{3}{*}{ Porcellanidae } & 2 & 18.3 & $<0.001$ & 2 & 13.8 & $<0.001$ & Early & A & A & B \\
\hline & & & & & & & Late & A & $\mathrm{AB}$ & B \\
\hline & & & & & & & PL & & ns & \\
\hline \multirow[t]{4}{*}{ Pagurus spp. } & 2 & 15.8 & $<0.001$ & 2 & 4.84 & $<0.001$ & Early & A & A & B \\
\hline & & & & & & & Mid & $\mathrm{A}$ & $\mathrm{B}$ & B \\
\hline & & & & & & & Late & $\mathrm{A}$ & A & $\mathrm{A}$ \\
\hline & & & & & & & PL & A & $\mathrm{AB}$ & B \\
\hline \multirow[t]{4}{*}{ Hemigrapsus spp. } & 2 & 17.1 & $<0.001$ & 2 & 5.79 & $<0.001$ & Early & A & $\mathrm{A}$ & B \\
\hline & & & & & & & Mid & A & $\mathrm{AB}$ & B \\
\hline & & & & & & & Late & & ns & \\
\hline & & & & & & & PL & A & A & A \\
\hline \multirow[t]{2}{*}{ Mimulus foliatus/Pugettia richii } & 2 & 10.6 & $<0.001$ & 2 & 4.42 & 0.01 & Early & $\mathrm{A}$ & $\mathrm{A}$ & B \\
\hline & & & & & & & Late & A & $\mathrm{AB}$ & B \\
\hline Scyra acutifrons/Pugettia producta & 2 & 5.83 & 0.004 & na & na & na & & $\mathrm{A}$ & $\mathrm{AB}$ & B \\
\hline Cancer magister & 2 & 3.81 & 0.03 & na & na & na & & A & $\mathrm{AB}$ & B \\
\hline \multirow[t]{2}{*}{ Cancer oregonensis/ Cancer productus } & 2 & 4.91 & 0.008 & 2 & 4.43 & 0.01 & Early & $\mathrm{A}$ & $\mathrm{AB}$ & B \\
\hline & & & & & & & Mid & & ns & \\
\hline \multicolumn{11}{|l|}{ Neuston } \\
\hline Lepas spp. & 2 & 8.89 & 0.0002 & na & na & na & & B & B & A \\
\hline \multicolumn{11}{|l|}{ No depth preference } \\
\hline Pachygrapsus crassipes & 2 & 1.8 & 0.17 & na & na & na & & & ns & \\
\hline
\end{tabular}


Table A3. 2-way ANOVA testing for differences in larval vertical distributions (depth) over the diel cycle (day/night). Day/night by depth interactions revealed whether larvae migrated into the upper water column during the night. All species of barnacles and pinnotherids occurred deep throughout the day while the remaining taxa migrated to the surface at night. Depths with different letters are significantly different $(p<0.05)$ according to the Tukey HSD test. ns: not significant

\begin{tabular}{|c|c|c|c|c|c|c|c|c|c|c|c|c|c|}
\hline \multirow[t]{2}{*}{ Species } & \multicolumn{3}{|c|}{ Day/Night } & \multirow[t]{2}{*}{ Day/ Night } & \multicolumn{3}{|c|}{ _Depth } & \multicolumn{3}{|c|}{ Day/Night × Depth } & \multicolumn{3}{|c|}{ Depth } \\
\hline & $\mathrm{df}$ & $F$ & $\mathrm{p}$ & & df & $F$ & $\mathrm{p}$ & $\mathrm{df}$ & $F$ & $\mathrm{p}$ & Bottom & Surface & Neuston \\
\hline \multicolumn{14}{|c|}{ Do not undergo diel vertical migration } \\
\hline Balanus crenatus & 1 & 4.54 & 0.04 & Night & 2 & 18.07 & $<0.001$ & 2 & 2.49 & 0.1 & A & $\mathrm{A}$ & B \\
\hline Balanus nubilus & 1 & 1.31 & 0.26 & ns & 2 & 1.8 & 0.18 & 2 & 2.81 & 0.08 & & ns & \\
\hline Balanus glandula & 1 & 0.7 & 0.41 & ns & 2 & 16.43 & $<0.001$ & 2 & 0.06 & 0.94 & $\mathrm{~A}$ & B & $\mathrm{C}$ \\
\hline Semibalanus cariosus & 1 & 2.58 & 0.12 & ns & 2 & 3.33 & 0.05 & 2 & 1.39 & 0.27 & $\mathrm{~A}$ & $\mathrm{AB}$ & B \\
\hline Chthamalus spp. & 1 & 1.1 & 0.3 & ns & 2 & 5.9 & 0.007 & 2 & 0.4 & 0.68 & $\mathrm{~A}$ & $\mathrm{AB}$ & B \\
\hline Pinnotheridae & 1 & 4.57 & 0.04 & Night & 2 & 3.6 & 0.04 & 2 & 2.12 & 0.14 & A & $\mathrm{AB}$ & B \\
\hline \multicolumn{14}{|c|}{ Undergo diel vertical migration } \\
\hline Neotrypaea californiensis & 1 & 4.31 & 0.05 & Night & 2 & 0.11 & 0.9 & 2 & 2.69 & 0.08 & & ns & \\
\hline Emerita analoga & 1 & 2.88 & 0.1 & ns & 2 & 3.7 & 0.03 & 2 & 11.7 & $<0.001$ & B & $\mathrm{AB}$ & A \\
\hline Porcellanidae & 1 & 7.13 & 0.01 & Night & 2 & 2.19 & 0.13 & 2 & 1.63 & 0.22 & & ns & \\
\hline Pagurus spp. & 1 & 0.28 & 0.6 & ns & 2 & 1.36 & 0.27 & 2 & 3.56 & 0.04 & & ns & \\
\hline Pagurid & 1 & 8.33 & 0.007 & Night & 2 & 0.09 & 0.91 & 2 & 2.44 & 0.1 & & ns & \\
\hline Hemigrapsus spp. & 1 & 1.51 & 0.23 & ns & 2 & 1.22 & 0.31 & 2 & 8.48 & 0.001 & & ns & \\
\hline Pachygrapsus crassipes & 1 & 0.2 & 0.66 & ns & 2 & 4.74 & 0.02 & 2 & 8.69 & 0.001 & B & $\mathrm{AB}$ & A \\
\hline $\begin{array}{l}\text { Mimulus foliatus/ } \\
\text { Pugettia richii }\end{array}$ & 1 & 8.21 & 0.008 & Night & 2 & 3 & 0.07 & 2 & 4.8 & 0.02 & & ns & \\
\hline $\begin{array}{l}\text { Scyra acutifrons/ } \\
\text { Pugettia producta }\end{array}$ & 1 & 9.49 & 0.004 & Night & 2 & 4.05 & 0.03 & 2 & 3.23 & 0.05 & B & $\mathrm{AB}$ & $\mathrm{A}$ \\
\hline Lophopanopeus bellus & 1 & 20.37 & $<0.001$ & Night & 2 & 1.06 & 0.36 & 2 & 3.07 & 0.06 & & ns & \\
\hline Cancer antennarius & 1 & 5.1 & 0.03 & Night & 2 & 3.92 & 0.02 & 2 & 8.76 & 0.001 & B & A & $\mathrm{AB}$ \\
\hline Cancer magister & 1 & 3.27 & 0.08 & ns & 2 & 3.23 & 0.05 & 2 & 7.75 & 0.002 & B & $\mathrm{AB}$ & A \\
\hline $\begin{array}{c}\text { Cancer oregonensis/ } \\
\text { Cancer productus }\end{array}$ & 1 & 0.2 & 0.65 & ns & 2 & 2.58 & 0.09 & 2 & 4.85 & 0.02 & & ns & \\
\hline
\end{tabular}

Editorial responsibility: William Peterson,

Newport, Oregon, USA
Submitted: August 24, 2009; Accepted: December 22, 2009 Proofs received from author(s): March 20, 2010 